\title{
Antiviral Potential of Selected Medicinal Herbs and Their Isolated Natural Products
}

\author{
W. P. R. T. Perera ${ }^{D},{ }^{1}$ Janitha A. Liyanage, ${ }^{2}$ K. G. C. Dissanayake, ${ }^{3}$ Hiruni Gunathilaka ${ }^{(D)},{ }^{4}$ \\ W. M. T. D. N. Weerakoon $\mathbb{D}^{2}$ D. N. Wanigasekara, ${ }^{5}$ W. S. K. Fernando, ${ }^{2}$ \\ R. M. H. Rajapaksha $\mathbb{D}^{6}{ }^{6}$ R. P. Liyanage, ${ }^{3}$ and Bingun T. Perera ${ }^{2}$ \\ ${ }^{1}$ Department of Indigenous Medical Resources, Faculty of Indigenous Health Sciences and Technology, \\ Gampaha Wickramarachchi University of Indigenous Medicine, Sri Lanka \\ ${ }^{2}$ Department of Chemistry, Faculty of Science, University of Kelaniya, Sri Lanka \\ ${ }^{3}$ Department of Cikitsa, Faculty of Indigenous Medicine, Gampaha Wickramarachchi University of Indigenous Medicine, Sri Lanka \\ ${ }^{4}$ Department of Rogavignana, Faculty of Indigenous Medicine, \\ Gampaha Wickramarachchi University of Indigenous Medicine, Sri Lanka \\ ${ }^{5}$ Department of Biochemistry, Faculty of Medicine, University of Ruhuna, Sri Lanka \\ ${ }^{6}$ Department of Chemistry, University of Iowa, USA \\ Correspondence should be addressed to W. P. R. T. Perera; 2017_perera@kln.ac.lk
}

Received 27 April 2021; Accepted 9 November 2021; Published 8 December 2021

Academic Editor: Hanchun Yang

Copyright (c) 2021 W. P. R. T. Perera et al. This is an open access article distributed under the Creative Commons Attribution License, which permits unrestricted use, distribution, and reproduction in any medium, provided the original work is properly cited.

\begin{abstract}
Viruses are responsible for a variety of human pathogenesis. Owing to the enhancement of the world population, global travel, and rapid urbanization, and infectious outbreaks, a critical threat has been generated to public health, as preventive vaccines and antiviral therapy are not available. Herbal medicines and refined natural products have resources for the development of novel antiviral drugs. These natural agents have shed light on preventive vaccine development and antiviral therapies. This review intends to discuss the antiviral activities of plant extracts and some isolated plant natural products based on mainly preclinical (in vitro and in vivo) studies. Twenty medicinal herbs were selected for the discussion, and those are commonly recognized antiviral medicinal plants in Ayurveda (Zingiber officinale, Caesalpinia bonducella, Allium sativum, Glycyrrhiza glabra, Ferula assafoetida, Gymnema sylvestre, Gossypium herbaceum, Phyllanthus niruri, Trachyspermum ammi, Withania somnifera, Andrographis paniculata, Centella asiatica, Curcuma longa, Woodfordia fruticose, Phyllanthus emblica, Terminalia chebula, Tamarindus indica, Terminalia arjuna, Azadirachta indica, and Ficus religiosa). However, many viruses remain without successful immunization and only a few antiviral drugs have been approved for clinical use. Hence, the development of novel antiviral drugs is much significant and natural products are excellent sources for such drug developments. In this review, we summarize the antiviral actions of selected plant extracts and some isolated natural products of the medicinal herbs.
\end{abstract}

\section{Introduction}

Many herbal remedies individually or in combination, as well as various formulations such as leaf powder, pastes, decoctions, infusions, and pills, have been recommended for different medical treatments, and numerous biologically active agents have been recognized for their various therapeutic functions. In the last few decades, thorough studies of phytochemicals for antiviral activities have assumed huge significance. A wide range of active phytochemicals, including flavonoids, terpenoids, organosulphur compounds, limonoids, lignans, sulfides, polyphenols, coumarins, saponins, chlorophyllins, furyl compounds, alkaloids, polyins, thiophenes, proteins, and peptides, has shown to have therapeutic applications against various genetically and functionally diverse viruses [1-5].

Medicinal plants have been used in the world, but their widespread use has been limited to the Asian region of the 
world such as China, India, Japan, Sri Lanka, and Thailand as well as some other African nations. However, developed countries are also working towards encouraging the use of natural medicinal products based on plant products in their healthcare systems [6].

Molecular pathways related to the antiviral effects of plant extracts may vary from virus to virus. However, the ability of plant extract to improve the inherent antiviral protection of the human body requires an intricate immune system $[7,8]$.

Plant-derived preparations have been made for centuries used to combat many diseases. Over the past few decades, natural phytochemicals have been tested for antiviral properties more specifically. However, owing to viral infections is becoming a significant threat to humans, further research work is still needed to gain effective knowledge about viral infections. In addition, medicinal plants are increasingly being suggested as suitable alternative sources of antiviral agents. Developing suitable in vitro pharmacodynamics screening techniques may contribute to the rapid identification of potential bioactive plants. Unfortunately, many antiviral compounds currently in clinical use have a narrow range of activity, minimal therapeutic utility, and variable toxicity [9-13].

Enhancement of the viral resistivity on the existing antiviral drugs and therapies is another challenge that the world population will face in the near future. In addition, the need to develop new antiviral drugs from the bioactive compounds of the plant is further exacerbated by the fact that viral infections are now recognized as the second most significant known cause of human cancer [14]. The main viral controlling mechanisms of bioactive compounds in medicinal herbs may include antioxidant activity, scavenging ability, inhibiting DNA, RNA synthesis, inhibiting viral entry, or inhibiting viral reproduction [15]. A significant number of plant-derived molecules exhibit antiviral activity, but their mechanical action needs to be explored. As medicinal plants have an infinite range of chemical constituents, they could be used to inhibit the replication of both DNA and RNA viruses [16].

Our intention of this review is to summarize the literature on antiviral bioactive compounds, discovered antiviral mechanisms, and antiviral actions of aqueous extracts of commonly used antiviral herbs in Ayurveda medicine.

\section{Methodology}

Literature searches were done regarding antiviral actions of the medicinal herbs in PubMed, PMC, and ScienceDirect. Furthermore, antiviral bioactive compounds of the selected herbs and their mechanisms were searched in some popular search engines like Google, Google Scholar, to gather secondary data. All materials, regardless of sources, were reviewed, and the review framework was developed to represent the information available. Chemical structures were prepared by using ChemDraw software.

\section{Results and Discussion}

3.1. Zingiber officinale. Ginger (Zingiber officinale), a member of the Zingiberaceae family and the genus Zingiber, has long been widely consumed as a spice and herbal medicine [17].

Gingerols (Figure 1) and shogaols are the phenolic compounds that are mainly responsible for the health benefits of dinger. Related research has shown that ginger has numerous biological activities, including antioxidant, anti-inflammatory, antimicrobial, anticancer, neuroprotective, cardiovascular, gastrointestinal, antiobesity, antidiabetic, and antinausea activities [18].

Fresh ginger was found to inhibit plaque formation induced by the human respiratory syncytial virus (HSRV) in respiratory tract cell lineages, and it is successful in blocking internalization and viral attachment. This analysis clearly showed that fresh ginger had antiviral activity on both HEp2 and A549 cells against HRSV. 300 milligrams/ $\mathrm{mL}$ in both cell types, fresh ginger reduced HRSV infection by more than $70 \%$. In addition to dried ginger, cells protect around $20 \%$ from viral plaque formation in only HEp-2 cells [19]. It reveals that the phytochemistry of ginger plays a major role in suppressing viral activities; once it is dried, antiviral activities are reduced due to lacking secondary metabolites.

The fresh ginger comprises [6]-, [8]-, and [10]-gingerols as the major pungent, and [4]- and [5]-gingerols contain trace amounts [20]. However, [6]-, [8]-, and [10]-gingerols are turned into shogaols during the commercial drying process [21], and dried ginger has not shown antiviral capabilities in most of the studies. Hence, it can be concluded that gingerols would be the most significant phytocompound inhibiting HRSV activities. But activity or the mechanism of the gingerols against HRSV has not been proven experimentally. In addition, HRSV binds and penetrates the $G$ proteins and F- fusion proteins, respectively, into the cells. Hence, fresh ginger should have a similar effect on HEp-2 and A549 cells [22].

3.2. Caesalpinia bonducella. Caesalpinia bonducella is often remembered as a "fever nut." The nut and nicker nut of Bondoc belong to the family of Caesalpiniaceae and have been recorded in Folklore Medicine and the ancient scriptures of Ayurveda. The seed of the C. bonducella contains Bonducin as the major active molecule. Apart from that, saponins and terpenoids are also known as other major secondary metabolites found in seeds. The shell contains fatty oil, starch, sucrose, phytosterols, stearic, palmitic, oleic, linoleic, linolenic, and a mixture of unsaturated fatty acids of low molecular weights $[23,24]$.

C. bonducella root extract has shown antiviral activity against the vaccinia virus. But details about viral controlling mechanisms and related phytocompounds have not been pointed out [25]. Further, phytochemicals in the seeds $C$. bonducella which are responsible for the antiviral activities and have not been identified separately and viral controlling mechanisms also have not clearly been reported in the literature. However, one of the computational investigations has discovered Taepeenin $\mathrm{J}$, as a promising candidate for the receptor inhibition process to mitigate cytokine storms due to the infection of the SARS-COV-19 virus. Taepeenin $j$ (Figure 2) is 1 of 12 cassane-type diterpenes readily found 


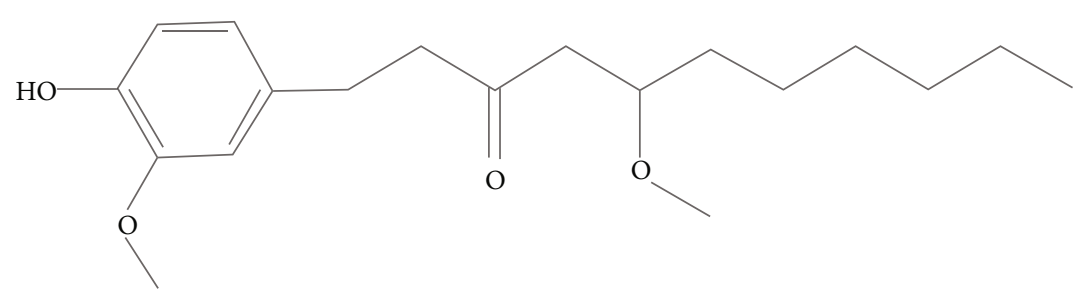

FIGURE 1: Chemical structure of the gingerols, a major phenolic compound that identified as the dominant constituent of both fresh and dried gingers.

in seeds of Caesalpinia species which belongs to the family of Caesalpiniaceae [26]. Hence, it can be suggested that more attention is needed to pay for the antiviral activities of the seeds related to the family of Caesalpiniaceae.

3.3. Allium sativum. Allium sativum, also known as garlic, one of the most common herbal remedies used in human history, dates back to ancient cultures [27]. The main bioactive compound of the A. sativum is allicin, and garlic extract with the allicin has been shown antiviral activities in vitro and in vivo due to sulfur-containing compounds such as allicin, diallyl disulfide, and diallyl trisulfide that react with thiol groups of various enzymes which are critical for microorganism surveillance $[28,29]$.

There are so many preclinical investigations that have been done to study antiviral activities of the different aqueous extracts of the A. sativum. According to one of the toxicity assays that were carried out using chicken embryos, an aqueous extract of the A. sativum has performed an antiviral effect against coronavirus species [30].

Meanwhile, another plaque reduction study suggests that aqueous extract in gold nanoparticles of $A$. sativum showed antiviral activity against the measles virus $(\mathrm{MeV})$ by direct inhibition of the virus via blocking the virus entry [31]. Herpes simplex virus- (HSV-) 1 and 2 viral inhibition assays also have been performed by direct preinfection incubation and plaque reduction assays with Vero and HeLa cell propagation methods. Those performances are also shown by aqueous extract in gold nanoparticles of $A$. sativum, and the proposed mechanism is inhibition of virus entry via disruption of the viral envelope and cell membrane [32]. Apart from that, early antigen assay has been done with extract of $A$. sativum against HCMV, human cytomegalovirus, and identified controlling mechanisms have been explained as inhibition of viral replication and boosting the immune response [33]. In addition to the fresh extract of garlic, the oil form of garlic also plays an important role in the inhibition of viruses. An antiviral experiment has been done using garlic oil against IBV influenza A virus-H1N1 via assessment of cytopathic effects in IAV-H1N1-infected cells and discovered reduced, visible cytopathic effects in IAV-H1N1infected cells [34]. Apart from water extract and oil extracts of the A. sativum, the $\mathrm{n}$-hexane extract also has examined for $\mathrm{HIV}$ reverse transcriptase inhibitory assay and positive results were obtained [35].

The organosulfur compounds extracted from A. sativum also have been investigated for different antiviral experiments, and its significant inhibition actions have been per- formed on different disease-forming viral species in human (Table 1).

3.4. Glycyrrhiza glabra. Glycyrrhiza glabra (licorice) has been well known in pharmacy for a long time. In the old ones, it was considered a first-class drug in Chinese pharmacy and the rejuvenating quality was attributed to it when ingested for long periods. Licorice has been used in ancient Egypt, Greece, and Rome [40]. Glycyrrhiza glabra contains different secondary metabolites that can be extracted from its roots and stem, and those are hydrophilic as well as biologically active. Glycyrrhizin is a major triterpenoid present in G. glabra which is responsible for the sweetness and taste of its roots [41].

Meanwhile, one of the significant antiviral studies reported that hot water extract preparations of the licorice have performed antiviral efficacy against the human respiratory syncytial virus (HRSV). Glycyrrhizin and $18 \beta$-glycyrrhetinic acid (18 $\beta-\mathrm{GA})$, the active phytochemicals in licorice, have been examined by plaque reduction assay in both human upper (HEp-2) and low (A549) respiratory tract cell lines. According to the results, one of the preparations of licorice called Radix Glycyrrhizae inhibited the HRSV induced plaque formation in both HEp-2 and A549 cell lines and those actions may be due to its inhibition of viral attachment and penetration into the host cells. Apart from that, $18 \beta$-GA (Figure 3 ) also showed a potent anti-HRSV activity $[12,41,42]$.

Other than HRSV, secondary metabolites of the G. glabra showed effective antiviral actions against influenza virus A2 (H2N2). According to studies conducted by Utsunomiya and his colleagues in 1997, it is suggested that the antiviral efficacy of glycyrrhizin is essentially due to the stimulation of $\beta$-interferon released by $\mathrm{T}$-cells. In this analysis, mice were selected to be infected with the influenza A2 (H2N2) virus. They were unable to tolerate and survive 10 times the lethal dose (LD50) of the virus. When treated with $10 \mathrm{mg}$ glycyrrhizin/kg at different periods, such as on the day before, on the day after, and on the fourth day after infection, complete survival was observed [43].

Glycyrrhizin (Figure 4) which is extracted from licorice as triterpenoid has performed more significant antiviral activates on some DNA and RNA-based viruses. It was able to inhibit the plaque formation of the herpes simplex virus (HSV-1 and HSV-2), and some inhibitory activity showed on polio type 1,2, and 3 as well as measles viral species. Further, glycyrrhizin is more effective in the regulation of viral replication and can be used as a prophylactic measure. It 


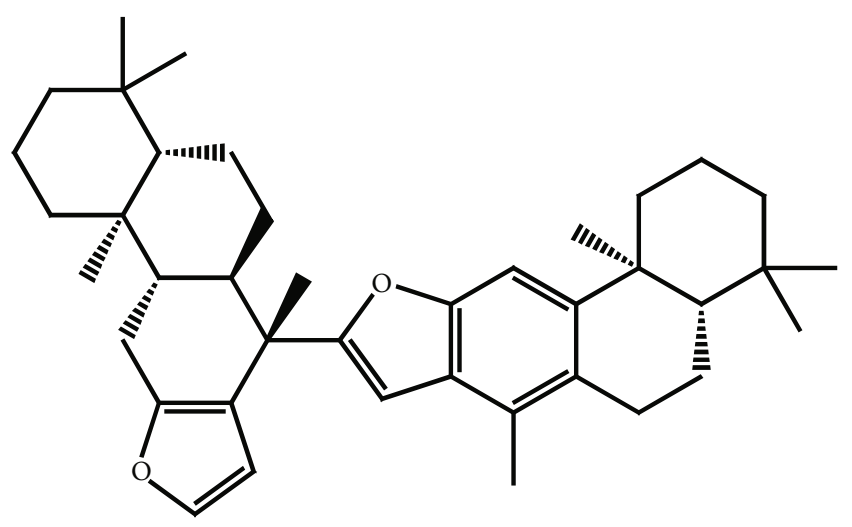

Figure 2: Chemical structure of the Taepeenin J, cassane-type diterpenes readily found in seeds of Caesalpinia species.

was also used to prevent the replication of the severe acute respiratory syndrome (SARS) coronavirus [44].

3.5. Ferula assafoetida. The oligo gum resins of Ferula assafoetida contain mainly five forms of sesquiterpene cumarine, namely, conferone, badrakemin, feslol, isosamarcandin, and samarcandin. These compounds vary depending on the presence or absence of the hydroxyl group, the position of the double bond, and the configuration of the chiral center. This means the main distinction between these compounds is due to the different sesquiterpene units $[45,46]$.

According to one study from the antiviral study group, CPE (cytopathic effect) inhibitory studies were done with Ferula assafoetida gum resin and its isolated sesquiterpene: Microlobidene (1), Farnesiferol C (2), Farnesiferol B (3), and Kellerin (4) (Figure 5). They were performed in HeLa cells with pleconaril-sensitive HRV-1A, 2, 14, and 16 in HeLa cells. Findings from CPE-inhibitory assays showed it has a dose-dependent antiviral activity against HRV-2 for asafetida gum resin. However, prevention of rhinovirus adsorption (HRV-2) is the mode of inhibition action [47]. Farnesiferol $\mathrm{C}$ and Farnesiferol $\mathrm{B}$ can be identified as novel chemical scaffolds having HRV-2 inhibiting potential where the micromolar range is low, while asafetida gum resin has been used for disorders of the upper respiratory tract [48].

Sesquiterpene coumarins, which are isolated from the resin of the $F$. assafoetida, have been demonstrated antiviral activity against the influenza $A$ virus ( $\mathrm{H} 1 \mathrm{~N} 1)$. According to the $\mathrm{IC}_{50}$ value calculations of this experiment, $8^{\prime}$-acetoxy$5^{\prime}$ S-hydroxyumbelliprenin, methyl galbanate, galbanic acid, Farnesiferol C, Farnesiferol A, and conferol (Figure 6) showed greater potency against influenza A virus (H1N1) $\left(\mathrm{IC}_{50} 0.26-0.86 \mu \mathrm{g} / \mathrm{mL}\right)$ than amantadine $\left(\mathrm{IC}_{50} 0.92 \mu \mathrm{g} / \mathrm{mL}\right)$, (positive control) [49],

3.6. Gymnema sylvestre. Gymnema sylvestre is native to central and western India, tropical Africa, and Australia [50]. The most abundantly found phytochemical groups in G. sylvestre leaves are triterpene and saponins. And other plant constituents are flavones, anthraquinones, hentriacontane, pentatriacontane, $\alpha$ and $\beta$-chlorophylls, resins, d-quercitol, tartaric acid, phytin, butyric acid, formic acid, lupeol, $\beta$ - amyrin-related glycosides, and stigmasterol. It is also positive for alkaloids, according to phytochemical investigations. The leaves of this species contain acid glycosides, anthraquinones, and their derivatives [51].

Some research studies have detected ethanolic and methanolic leaf extract activity of G. sylvestre against HIV-1, reverse transcriptase (RT) enzyme, HBV DNA polymerase enzyme, and HBsAg assays. The effect was evaluated using a nonradioactive HIV-RT colorimetric kit. The binding activity of HBsAg was evaluated using the ELISA kit and the activity of HBV DNA polymerase using the Radiometric Kit. Inhibition of 50 percent (IC50) was considered a positive activity. The methanolic extract was found to possess potent in vitro HBsAg binding, inhibition of HBV DNA polymerase, and inhibition of HIV-1 RT activity, whereas ethanolic extracts are positive for inhibition of $\mathrm{HIV}-1$ RT [52].

Reports on G. sylvestre indicate that the plant leaves have nutritional and medicinal value in the extracts of leaf, stem, root, and fruit that are important from the research point of view [53]. And also, they have shown the antiviral properties of phytochemicals like triterpenoid saponins [54] and gymnemic acids [55].

3.7. Gossypium herbaceum. Gossypium herbaceum is known as a cotton plant, belongs to the Malvaceae family, and is widely distributed throughout western India, middle east countries, Africa, Central Asia, Iran, Russia, Afghanistan, and Turkey. The qualitative phytochemical investigations of these plant extracts indicate the presence of carbohydrates, saponins, glycosides, steroids, phenolic compounds such as flavonoids, and tannins [56].

The key pigment of cotton seed was gossypol (Figure 7), a phenolic compound that was first isolated in 1899. Researchers have found that this compound has antiviral properties against enveloped viruses, including HIV-1, HSV-2, influenza, and parainfluenza [57].

Incubation of HTLV-III B strain of human immunodeficiency virus with gossypol has shown that it can prevent the recovery of viable viruses when subsequently incubate with H9-T cells [58]. Variety analogs of gossypol displayed more activity against type 1 (HIV-l) immunodeficiency virus, while the racemic mixture and both gossypol enantiomers prevented the replication of type 1 (HIV-l) human immunodeficiency virus [59].

Water extracts of Gossypium hirsutum leaves have also been investigated for the antiviral effect against the yellow fever virus in the tissue cell culture using Vero cells. The extracts demonstrated antiviral activity against the yellow fever virus by inhibiting the yellow fever virus in MICs of $0.079 \mathrm{mg} / \mathrm{mL}[60]$.

3.8. Phyllanthus niruri. Phyllanthus niruri is a perennial tropical traditional shrub of the Phyllanthaceae family with long-standing Ayurveda, Chinese, and Malay ethnomedical records. Preliminary studies from cell and animal models have provided valuable scientific evidence for its use which has been used for a wide range of diseases in South and Southeast Asian traditional medicine [61]. 
TAble 1: Preclinical investigations of viral inhibition assays of organosulfur compounds which isolate from A. sativum.

\begin{tabular}{|c|c|c|c|c|}
\hline $\begin{array}{l}\text { Organosulfur } \\
\text { compound }\end{array}$ & Detection method & Virus species & Antiviral mechanism & Reference \\
\hline Allicin & $\begin{array}{l}\text { Direct preinfection } \\
\text { incubation and plaque } \\
\text { reduction assay }\end{array}$ & $\begin{array}{l}\text { Herpes simplex virus-1 } \\
\text { Herpes simplex virus-2 } \\
\text { Parainfluenza virus-3 } \\
\text { Vaccinia virus } \\
\text { Vesicular stomatitis virus } \\
\text { Human rhinovirus type } 2\end{array}$ & $\begin{array}{l}\text { Disruption of viral envelop and } \\
\text { cell membrane }\end{array}$ & {$[32]$} \\
\hline Alliin & Anti-inflammatory assay & Dengue virus & $\begin{array}{l}\text { Inhibition of inflammation via reduction of } \\
\text { oxidative stress }\end{array}$ & {$[36]$} \\
\hline \multirow{3}{*}{ Ajoene } & Anti-HIV activity & Human immunodeficiency virus-1 & $\begin{array}{l}\text { Prevention of induced destructions of } \\
\qquad \mathrm{CD}+\text { cells }\end{array}$ & {$[32]$} \\
\hline & $\begin{array}{l}\text { HIV-infected platelet } \\
\text { aggregation and fusion } \\
\text { assays }\end{array}$ & Human immunodeficiency virus & $\begin{array}{l}\text { Inhibition of adhesive bonds and fusion of } \\
\text { leukocytes }\end{array}$ & {$[37]$} \\
\hline & $\begin{array}{l}\text { HIV induced cellular } \\
\text { toxicity assay }\end{array}$ & Human immunodeficiency virus-1 & $\begin{array}{l}\text { Inhibition of viral reverse transcriptase and } \\
\text { cell attachment }\end{array}$ & {$[38]$} \\
\hline $\begin{array}{l}\text { Allyl methyl } \\
\text { thiosulfinate }\end{array}$ & $\begin{array}{l}\text { Direct preinfection and } \\
\text { plaque reduction assay }\end{array}$ & $\begin{array}{c}\text { Herpes simplex virus-1 } \\
\text { Herpes simplex virus-2 } \\
\text { Parainfluenza virus-3 } \\
\text { Vaccinia virus } \\
\text { Vesicular stomatitis virus } \\
\text { Human rhinovirus type } 2 \\
\end{array}$ & $\begin{array}{l}\text { Disruption of viral envelop and } \\
\text { cell membrane }\end{array}$ & {$[32]$} \\
\hline Diallyl trisulfide & Plaque reduction assay & $\begin{array}{l}\text { Human cytomegalovirus; } \\
\text { IAV-H1N1 }\end{array}$ & $\begin{array}{l}\text { Inhibit viral DNA synthesis through } \\
\text { inhibition of HCMV immediate early } \\
\text { antigen expression }\end{array}$ & {$[39]$} \\
\hline $\begin{array}{l}\text { Diallyl sulfide } \\
\text { and Diallyl } \\
\text { disulfide }\end{array}$ & $\begin{array}{l}\text { Oxidative stress and anti- } \\
\text { inflammatory assay }\end{array}$ & Dengue virus & Reduction of oxidative stress & {$[36]$} \\
\hline
\end{tabular}

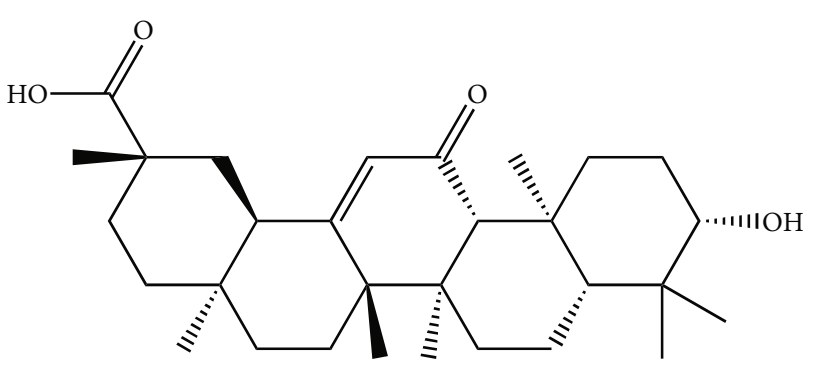

FIGURE 3: $18 \beta$-glycyrrhetinic acid $(18 \beta$-GA), the active phytochemicals in licorice which performed antiviral activity against HRSV.

Antiviral activity is the most prominent among the potential therapeutic effects of $P$. niruri. Studies conducted by obtaining chronic hepatitis B patients and woodchuck hepatitis- (WHV-) infected woodchucks, which were treated with extracts of this plant, showed decreased viral antigen levels [62]. Aqueous extracts of $P$. niruri have been shown to possess significant antiviral potential and found to be a promising approach for hepatitis B carriers [63].

The antiviral activity of $P$. niruri is not just limited to the hepatitis $\mathrm{B}$ virus, but also aqueous extracts of $P$. niruri containing repandusinic acid (Figure 8), a hydrolyzable tannin, have been shown to apply a significant inhibitory effect on HIV-1 reverse transcriptase [64]. According to the kinetic analysis, it has been suggested that repandusinic acid competitively inhibits the template primer during the process of reverse transcription [62].

In addition, various members of the Phyllanthus family have exhibited inhibitor activity against a wide range of viruses, such as hepatitis $B$ virus (HBV), hepatitis $C$ virus (HCV), human immunodeficiency virus (HIV), and herpes simplex virus (HSV) [65].

3.9. Trachyspermum ammi. Trachyspermum ammi, also known as ajwain from the Apiaceae family, is an old herb with various medicinal properties. The oil extracted from the seeds of $T$. ammi from the Apiaceae family showed remarkable antibacterial, antiviral, antifungal, antitussive, anti-inflammatory, and analgesic effects [66].

Japanese encephalitis virus (JEV) titer has been determined by plaque assay in vitro, and ajwain oil antiviral activity was quantified by a plate-reduction neutralization test (PRNT). Their data suggested that ajwain oil has possible in vitro antiviral activity against JEV. Furthermore, the active biomolecule (thymol) present in ajwain oil must be investigated in order to explore its potential for antiviral drugs in the future [67].

3.10. Withania somnifera. Withania somnifera, is a very valuable medicinal herb and commonly known as "Ashwaghanda." It belongs to the genus of Withania and the family 


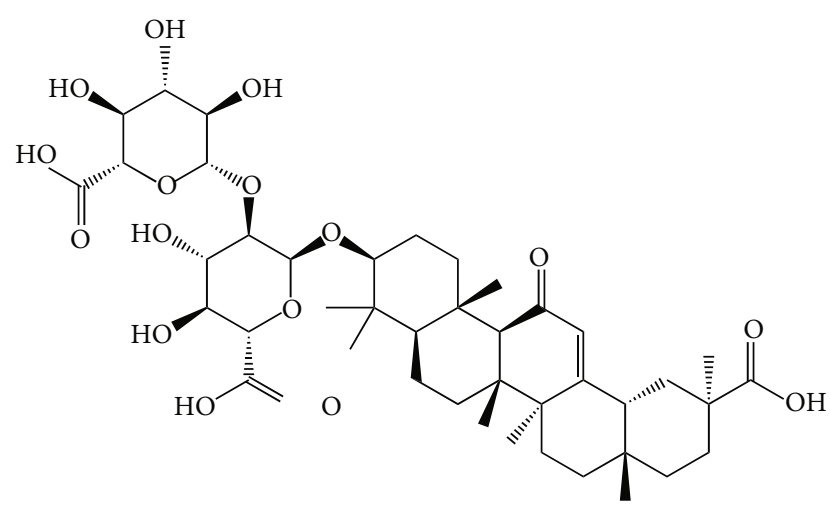

FIGURE 4: Chemical structure of the glycyrrhizin, natural saponin composed in G. glabra root/stem extract.

of Solanaceae and is found in Asian countries, including India [68]. Laboratory research has shown that there are more than 35 chemical components at the root of $W$. somnifera [69].

Biologically active chemical constituents of this plant are alkaloids (isopelletierine, anferine), steroidal lactones (withanolides, withaferins), saponins containing additional classes of acyls, and withanoloids containing glucose [70].

Many researchers studied the antiviral function of these plant extracts against the replication of the Infectious Bursal Disease virus. W. somnifera roots hydroalcoholic extract demonstrated inhibition of the virus at a maximum of $99.9 \%$ at its maximum nontoxic concentration, $25 \mu \mathrm{g} / \mathrm{mL}$ in the cytopathic effect reduction assay [71].

$W$. somnifera extract also demonstrated antiviral activity against the herpes simplex type-1 virus. $W$. somnifera and Aloe ferox are widely used to treat sexually transmitted infections (STIs). Aqueous extracts of these two species, together with aloin which is isolated from A. ferox, have been tested for in vitro antiviral potential against herpes simplex virus type 1 (HSV-1). Aqueous extracts of $W$. somnifera have shown significant activity against the virus in the Vero cells of African green monkey cell culture [72].

The inhibitory potential of Withaferin A (Figure 9) which is a steroid present in $W$. somnifera against herpes simplex virus has also been evaluated. Researchers conducted docking and further molecular dynamic simulation studies to elucidate the mechanism of binding of prospective herbal drug withaferin A to the structure of the herpes simplex virus's DNA polymerases [73]. And also W. somnifera has demonstrated antiretroviral actions against HIV infections [74].

3.11. Andrographis Paniculata. Andrographis paniculata which is also known as "king of bitters" belongs to the family Acanthaceae. Most countries like India, China, Malaysia, and Thailand have been used this herbaceous plant to treat many illnesses from ancient times [75].

A.s paniculata is well known for its antiviral, antibacterial, and antifungal properties. Methanolic extracts while the aqueous extract of $A$. paniculata has tested in the H9 cell line against HIV and it had reported inhibitory activity against HIV [75].
The main constituents of $A$. paniculata are flavonoids, diterpenoids, and polyphenols. Andrographolides are the major bioactive phytoconstituent, found in A. paniculata.

This phytoconstituent was tested for antiviral activity against herpes simplex virus (HSV) [76], human immunodeficiency virus (HIV) [77], flaviviruses [78], and pestiviruses [79]. It has been demonstrated that the ethanolic extract of $A$. paniculata $(25 \mu \mathrm{g} / \mathrm{mL})$ and andrographolide (Figure 10) $(5 \mu \mathrm{g} / \mathrm{mL})$ has a pronounced effect in inactivation or the inhibition of Epstein Virus (EBV) lytic proteins, Rta, Zta, and EA-D expression in P3HR1 cells.

According to a recent study, A. paniculata exhibits an antiviral inhibitory effect against DENV1-infected Vero E6 cells [80]. Apart from antiviral properties, it exhibits many useful properties like hypolipidemic effect, antihyperglycemic activities, antipyretic and analgesic effects, and antimalarial effects [75].

3.12. Centella asiatica. Centella asiatica is commonly known as "Gotu kola" in Sri Lanka and China, Mandukparni or Indian pennywort, or jalbrahmi in India. This herbaceous plant is also used by people in the Indonesian islands and Java as a medicinal plant [81].

The major active components of $C$. asiatica are triterpenoids (saponins) which include asiaticosides [82]. This compound is responsible for the vascular effects and wound healing effects by inhibiting the production of collagen at the wound site. Apart from that, total plant extract contains flavonoids and plant sterols [83]. Major triterpenoids include asiatic acid, asiaticoside, madecassic acid, madasiatic acid, madecassoside, and isothankunic acid [84].

Crude water extract of $C$. asiatica exhibits antiherpes simplex activity. C. asiatica has shown anti-HSV-1 and 2 inhibition abilities via plate inhibition assay (with median effective dose $\left(\mathrm{ED}_{50}\right)$ which was $362 \mu \mathrm{g} / \mathrm{ml}$ and $298 \mu \mathrm{g} / \mathrm{ml}$ for HSV-1 and HSV-2, respectively) [85]. In addition to that, another research group has revealed methanolic and aqueous extracts of the $C$. asiatica as an excellent virucidal, prophylactic, and marked antiviral attachment activities with relevant assays against pseudorabies virus (PrV) as well as it was discovered that methanolic extract of $C$. asiatica was acting as most active antiviral attachment agents with percent cell viability up to $60 \%$ among other tested plant extracts [86].

Though there are fewer reports regarding the antiviral properties of C. asiatica, there are many publications regarding other pharmacological properties of C. asiatica. Antibacterial, antifungal, antiulcer, and antidiabetic activity and anti-inflammatory activity are some of them [81].

3.13. Curcuma longa. Curcuma longa in which rhizome is commonly named as turmeric is an ancient coloring agent with various medicinal properties which belong to the family Zingiberaceae. The major phytochemicals found in C. longa is curcumin (Figure 11) with the chemical formula "1,7-bis (4-hydroxy-3-methoxyphenyl-1,6-heptadiene-3,5-dione).” The content of curcumin in C. longa varies with geographical features [87]. 


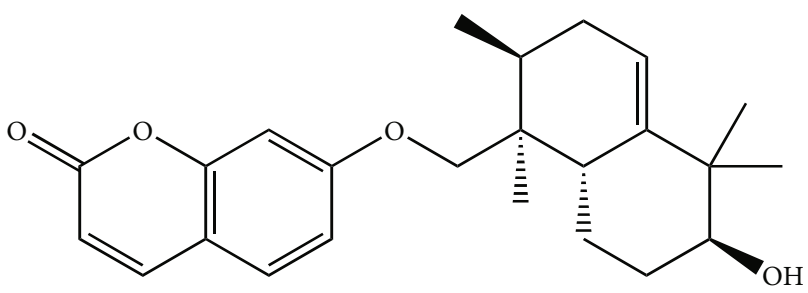

(a) Microlobidene

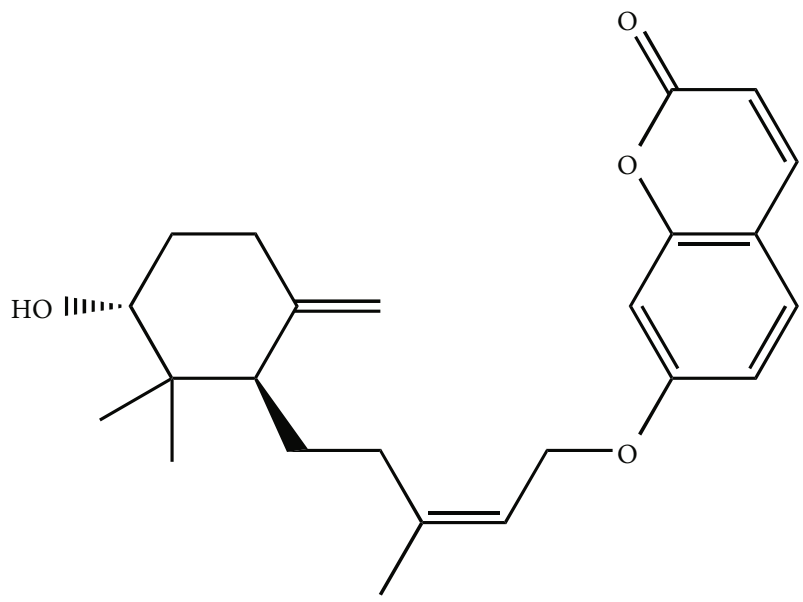

(c) Farnesiferol b

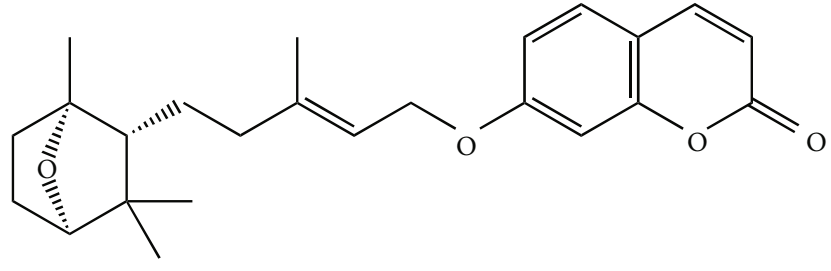

(b) Farnesiferol c<smiles></smiles>

FIGURE 5: Sesquiterpene cumarines isolated from oligo-gum resin of Ferula assafoetida showed antiviral properties against rhinovirus (HSV).

Curcumin as the major constituent in C. longa has a wide range of antiviral activity against many viral diseases. The bioconjugates of curcumin such as di-O-pamitoyl curcumin, di$O$-bis- $(\gamma, \gamma)$ folyl curcumin, di-O-tryptophanylphenylalanine curcumin, di-O-decanoyl curcumin, and $\mathrm{C}^{4}$-ethyl- $O-\gamma$-folyl curcumin have antiviral properties against parainfluenza virus type 3 (PIV-3), vesicular stomatitis virus (VSV), feline infectious peritonitis virus (FIPV), herpes simplex virus (HSV), respiratory syncytial virus (RSV), and Flock House virus (FHV) [87]. MTT assay results had depicted antiviral properties against different viral pathogens in further studies.

Apart from that, curcumin showed anti-influenza activity against influenza viruses PR8, H1N1, and H6N1. The test results showed a more than $90 \%$ reduction in virus yield in cell culture using $30 \mu \mathrm{M}$ of curcumin [88]. Curcumin as well as its derivatives show antiviral activity against herpes simplex virus type-1 (HSV-1) [89].

Human papillomaviruses (HPVs) are highly risk viruses, and the expression of E6 and E7 viral oncoprotein has the main role in cervical carcinoma. Curcumin which is the main constituent of $C$. longa has the inhibitory activity against the expression of E6 and E7 genes of two types of HPVs which are highly oncogenic human papillomaviruses [90]. According to the investigation of the antiviral function of curcumin on Neuro 2 cell line infected with the Japanese encephalitis virus, the inhibition of the ubiquitinproteasome system has resulted while reducing the occurrence of infectious particles [91]. Apart from that, curcumin exhibits antibacterial activity, synergistic antimicrobial activity, antibiofilm activity, and antifungal activity.
3.14. Woodfordia fruticosa. Woodfordia fruticos is commonly known as fire flame bush and Shiranjitea, and it belongs to the family Lythraceae. This plant can be seen most prevalently in Sri Lanka, India, Indonesia, Malaysia, China, and Japan. Various parts of these plants like stem, leaves, and flowers had been used from ancient times as medicine. W. fruticosa flower has been used for treating diarrhea, internal hemorrhages, dysentery, leucorrhoea, and menorrhagia [92].

The major constituent in flowers is tannins. Chrysophenol-8-O- $\beta$-D-glucopyranoside, $\beta$-sitosterol, cyanidin-3.5diglucoside, and octacosanol also have been extracted from flowers. Leaves contain ellagic acid, myricetin-3-galactoside, pelargonidin-3,5-diglucoside, and polystachoside. The plant also contains trimeric and tetrametric hydrolyzable tannins $[69,93]$.

W. fruticos has many pharmacological properties such as antiulcer properties [94], immunomodulatory activity [95], hepatoprotective activity [96], antitumor activity [97], and wound healing activity [98]. During viral infection, reactive oxygen species are produced by the action of viruses which causes damages to the infected cells. Antioxidant which has the ability to reduce the reactive oxygen species exhibits some antiviral properties. Extracts of $W$. fruticosa flowers were found to have excellent antioxidants that trigger the antiviral activity [99].

At the same time, $W$. fruticosa has antiviral activity against enterovirus. Aqueous and methanolic extracts of $W$. fruticosa flowers and leaves inhibited avian myeloblastosis virus reverse transcriptase. Even at the extract 
<smiles>CC(C)=CCCCC(C)C[C@H](O)C/C(C)=C/COc1ccc2ccc(=O)oc2c1</smiles>

(a)<smiles>COC(=O)CC[C@H]1C(=C(C)C)CC[C@H](C)[C@@]1(C)COc1ccc2ccc(=O)oc2c1</smiles>

(c)<smiles>COC(=O)CC[C@H]1C(=C(C)C)CC[C@H](C)[C@@]1(C)COc1ccc2ccc(=O)oc2c1</smiles>

(b)<smiles>CC1=CC[C@H]2C(C)(C)[C@H](O)CC[C@]2(C)[C@H]1COc1ccc2ccc(=O)oc2c1</smiles>

FIGURE 6: Sesquiterpene cumarines isolated from oligo-gum resin of Ferula assafoetida against showed antiviral properties against influenza A H1N1 virus: (a) $8^{\prime}$-acetoxy-5'S-hydroxyumbelliprenin, (b) methyl galbanate, (c) galbanic acid, and (d) conferol.<smiles>Cc1cc2c(C(C)C)c(O)c(O)c(C=O)c2c(O)c1-c1c(C)cc2c(C(C)C)c(O)c(O)c(C=O)c2c1O</smiles>

Figure 7: The structure of gossypol, an active antiviral compound found in the principle pigment of cotton (Gossypium herbaceum).

concentration which shows $90 \%$ inhibition, there had been no cytotoxicity observed. Gallic acid present in flower extract exhibits antiherpes simplex type-1 virus and antihuman immunodeficiency virus activity [100].

3.15. Phyllanthus emblica. Phyllanthus emblica is a member of the Euphorbiaceae family, and it has widely distributed in most tropical and countries. The fruit of the P. emblica is one of the most powerful and widely used herbal medicines in the Ayurvedic and Unani medicinal systems [101].
Ascorbic acid (vitamin C) is the most abundant component of P. emblica fruit. Also, other phytochemicals extracted from this plant are included fixed oils, phosphates, essential oils, tannins, minerals, vitamins, amino acids, and fatty acids. The fatty acids identified by $P$. emblica are linolenic, linoleic, oleic, stearic, palmitic, and myristic acids. D-glucose, D-fructose, D-myositol, D-galacturonic acid, D-arabinose, D-rhamnosyl, D-xylosyI, D-glucosyI, D-mannosyl, and $\mathrm{D}$-galactosyI residue are sugars. The major tannins identified in the plant are emblicanin A, emblicanin B, pedunculagin, and punicgluconin [102].

A polyphenol compound isolated from $P$. emblica, named 1,2,4,6-tetra-O-galloyl- $\beta$-D-glucose (Figure 12), has been documented in vitro for antiviral activity against herpes simplex virus. It shows that the inhibition of herpes simplex virus type-1 (HSV-1) and HSV-2 is in different magnitudes. Further studies suggest this compound inhibited HSV-1 viral attachment in the early stage by blocking viral attachment and penetration. Additionally, due to the presence of 1,2,4,6-tetra-O-galloyl- $\beta$-D-glucose, viral protein synthesis processes also have been reduced [103].

Phyllaemblicin B and phyllaemblicin C and phyllaemblic acid methyl ester extracted from the roots of the P. emblica exhibited antiviral activity against coxsackievirus B3 (CVB3) in an in vitro cytopathic inhibitory assay. Half maximum inhibitory concentrations (IC50) have reported as $7.8 \mu \mathrm{g} / \mathrm{mL}, 11.0 \mu \mathrm{g} / \mathrm{mL}$, and $21.8 \mu \mathrm{g} / \mathrm{mL}$ for phyllaemblicin 


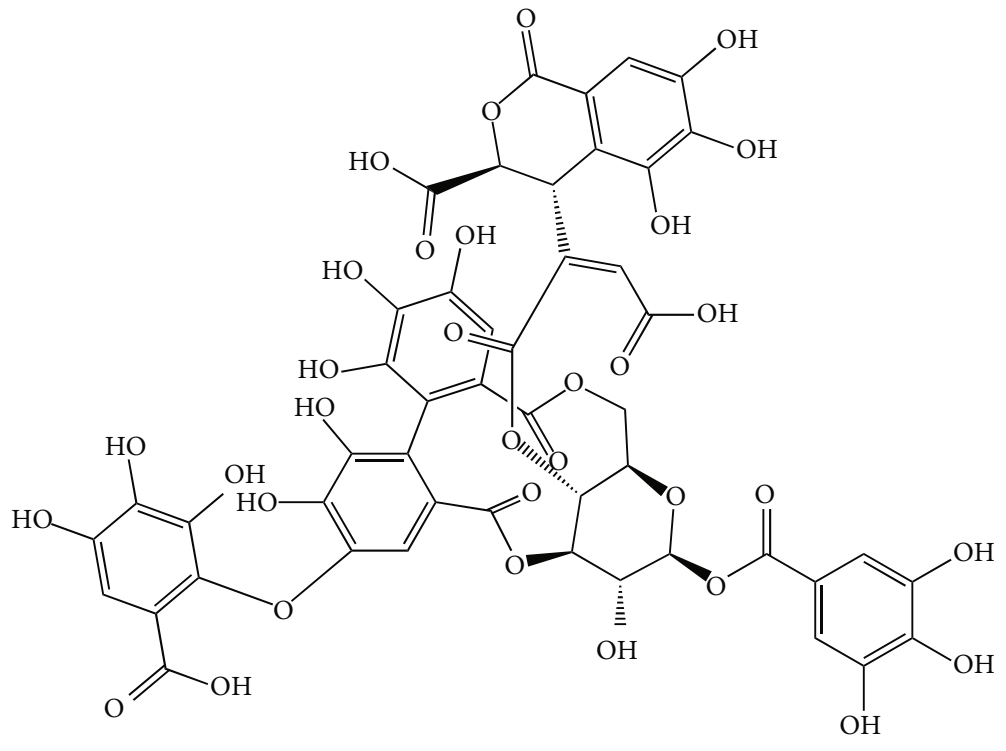

Figure 8: Chemical structure of the repandusinic acid, a hydrolyzable tannin, contains a significant inhibitory effect on HIV-1 reverse transcriptase.

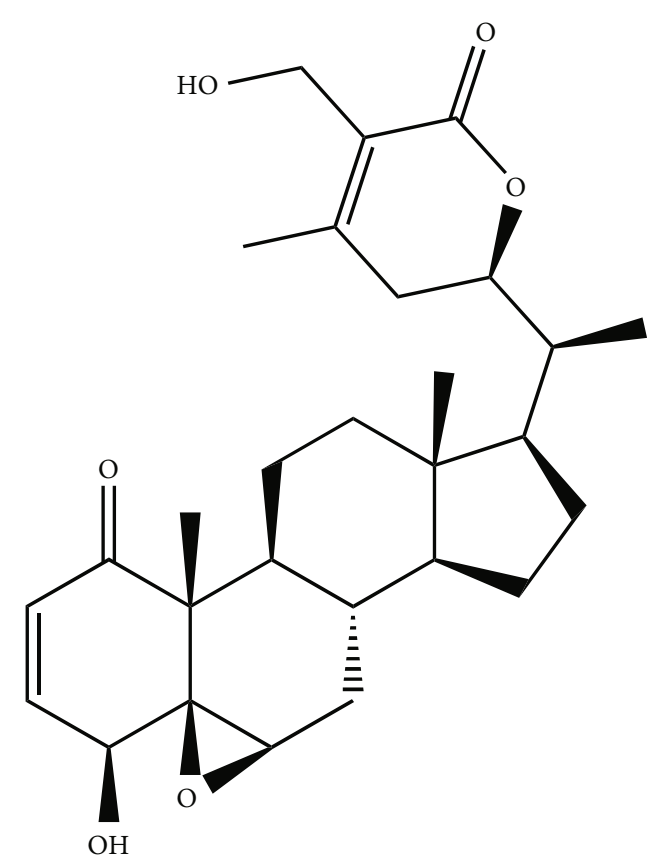

Figure 9: Structures of Withaferin A, a steroidal compound present in Withania somnifera.

B, and phyllaemblicin C and phyllaemblic acid methyl ester, respectively, and ribavirin considered as control and its IC50 value reported as $20.3 \mu \mathrm{g} / \mathrm{mL}$ explaining phyllaemblicin B, and phyllaemblicin $\mathrm{C}$ and phyllaemblic acid methyl ester are potential candidates for natural anticoxsackievirus B3 agents [104].

In the meantime, another study found that some of the highly oxygenated bisabolane sesquiterpenoid glycoside phyllaemblicins isolated from the P. emblica have possible antihepatitis B virus (HBV) activities [105]. In the roots of many Phyllanthus spp., bisabolane sesquiterpenoid glycosides which are highly oxygenated are present. In addition, the key components of the root extract of Phyllanthus emblica, phyllaemblicin $\mathrm{B}$, and glochicoccinoside $\mathrm{D}$ showed potential antiviral activity against influenza A virus strain $\mathrm{H} 3 \mathrm{~N} 2$ and hand, foot, and mouth virus EV71 (H3N2 and EV71). Furthermore, the identified glochicoccinoside D exhibited potent antiviral efficacy against hand, foot, and mouth virus EV71 and influenza A virus strain $\mathrm{H} 3 \mathrm{~N} 2$ with $\mathrm{IC}_{50}$ values; $2.6 \pm 0.7 \mathrm{mg} / \mathrm{mL}$ and $4.5 \pm$ 0.6 , respectively.

3.16. Terminalia chebula. Terminalia chebula is a native plant in India. It belongs to the family Combretaceae. It is a very common medicinal plant in Unani, Ayurveda, and homeopathy [106]. Rural folks used this plant to treat asthma, heartburn, vomiting, dysentery, sore throat, and ulcers. The main phytochemical constituents in T. chebula are tannins and polyphenols like ellagic acid, anthraquinones, chebulinic acid, corilagin, galloylglucose, and triterpenes [107].

T. chebula has antiviral properties. It has the ability to fight against the influenza A virus to protect the upper respiratory cells and also helps to prevent pulmonary infections [108]. In different studies regarding T. chebula constituents had demonstrated its ability to heal the herpes simplex virus [109]. In the literature, it has mentioned the ability of T. chebula to inhibit the activity of reverse transcriptase and protease of human immunodeficiency virus-1 [110]. Apart from that, a group of investigators looked at the antiviral activity of T. chebula on human cytomegalovirus (CMV) and plant extract of T.chebula was involved in the prevention of CMV replication in immune-compromised mice and determined that it could be useful to inhibit CMV infections in immune-compromised patients as well [111]. 


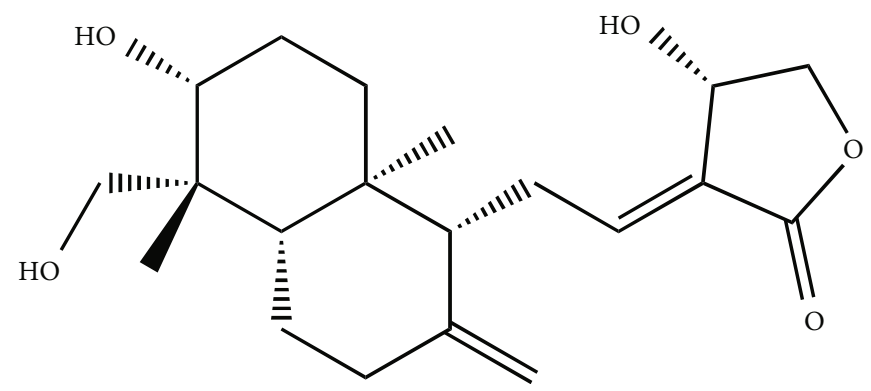

FIGURE 10: Structure of andrographolide, major phytoconstituent in Andrographis paniculata.<smiles>COc1cc(/C=C/C(=O)CC(=O)/C=C/c2ccc(O)c(OC)c2)ccc1O</smiles>

FIGURE 11: Structure of curcumin as the major constituent in C. longa.<smiles>O=C(OC[C@H]1O[C@@H](OC(=O)c2cc(O)c(O)c(O)c2)[C@H](O)[C@H](OC(=O)c2cc(O)c(O)c(O)c2)[C@@H]1OC(=O)c1cc(O)c(O)c(O)c1)c1cc(O)c(O)c(O)c1</smiles>

Figure 12: Structure of 1,2,4,6-tetra-O-galloyl- $\beta$-D-glucose, a polyphenolic compound isolated from Phyllanthus emblica.

Tannins can be extracted from T. chebula and it has a pronounced effect in plant pathogenic potato virus [112]. And also according to the results of recent research, constituents such as chebumeinin A, chebumeinin B, and some other hydrolyzable tannins in the dried fruit of T.chebula have the possibility to react against hepatitis $\mathrm{C}$ virus [113].
3.17. Tamarindus indica. Tamarind or Tamarindus indica belonging to Fabaceae, a subfamily of Caesalpinioideae, is an important food in the tropics. It is a multipurpose tree, almost every part of which has at least some kind of nutritional or medicinal function. Tamarind is native to tropical Africa but has been spread to most of the world's regions [114]. 


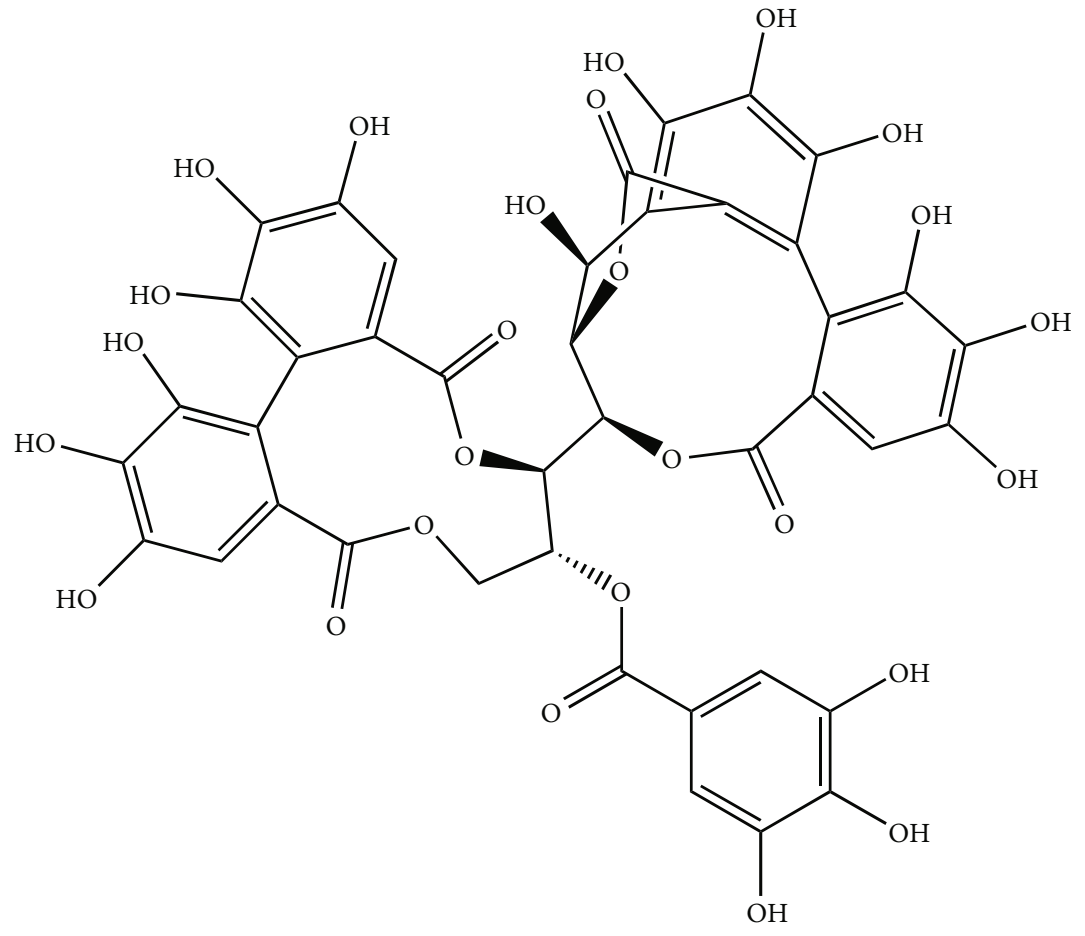

Figure 13: Structure of casuarinin, a hydrolyzable tannin isolated from the Terminalia arjuna bark.

Tamarind leaves are a fair source of vitamin $\mathrm{C}$ and carotene; the mineral content is high, especially $\mathrm{P}, \mathrm{K}, \mathrm{Ca}$, and $\mathrm{Mg}$. The antioxidant, anti-inflammatory, antimicrobial, and antifungal activity has been reported from many plant sections, and Tamarind fruit pulp has a sweet acidic taste due to a combination of high tartaric acid content and reducing sugar content [115]. Phenol-rich food and drinks including red wine, grapes seeds, green tea, and Tamarind have a hypolipidemic, antiatherosclerotic, antioxidant, anti-inflammatory, and immunomodulatory impact. In particular, the rich content of polyphenols in seed and fruit has a beneficial impact on neutrophils. T. indica fruit extract has been shown to inhibit watermelon mosaic virus, cowpea mosaic virus, and tobacco mosaic virus as an effective antiviral capability on plant-infected viruses [116].

Inhibition of virus replication and/or virucidal function of $T$. indica, stem bark, crude ethanol extract, and column chromatographic fractions tested for velogenic Newcastle disease virus (NDV) and showed positive activity, and minimum inhibitory concentrations of bark extract for virus inactivation was $0.24 \mathrm{mg} / \mathrm{mL}$ [117].

3.18. Terminalia arjuna. Terminalia arjuna initially was referred to as "Hirdya" a drug that strengthens the heart, but further research and clinical evidence indicate that it also possesses strong anticancer and antiviral activity [118].

Significant chemical components present in the plant triterpenoids are primarily responsible for cardioactive properties. Tannins are responsible for anticancer and antiherpes simplex virus (HSV) and polyphenols, including flavonols and flavonols. Phenylpropanoids are also useful for cancer treatment [119].

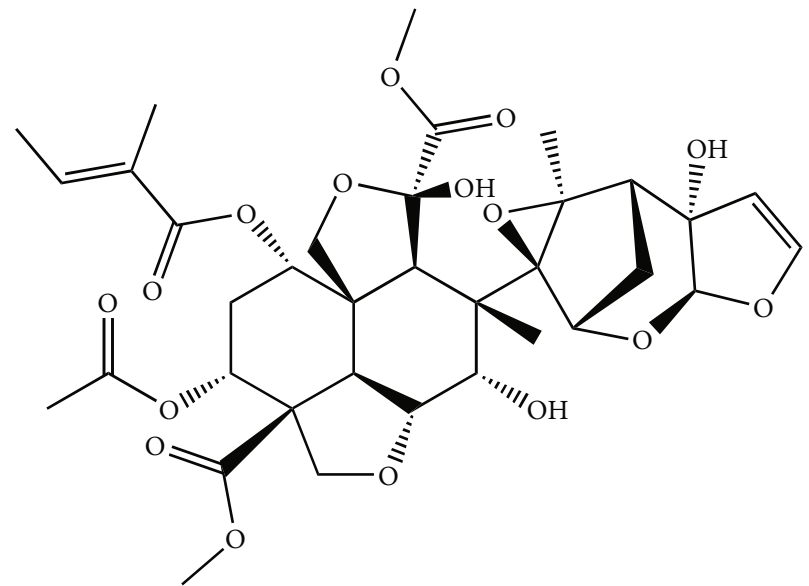

FIgURE 14: Structure of azadirachtin contains in the seed of the Azadirachta indica which recognize as major constituent for antiintertidal properties.

Casuarinin (Figure 13), a hydrolyzable tannin isolated from the T. arjuna bark has antiviral activity on herpes simplex type 2 viruses (HSV-2) in vitro. IC50 value of casuarinin in sodium 30-[1-(phenylamino-carbonyl)-3,4tetrazolium]-bis (4-methoxy-6 nitro) benzene sulphonic acid (XTT) and plate reduction assays were found to be $3.6 \pm 0.9$ and $1.5 \pm 1.00$ microgram. Casuarinin has also been shown to prevent HSV-2 from being bound to cells. It also exhibited active inhibition of viral penetration [120].

In the meantime, another research group performed a critical antiviral experiment using aqueous leaves extract $T$. 
TABLE 2: Summary (phytocompounds and antiviral mechanisms).

\begin{tabular}{|c|c|c|c|}
\hline Phytocompound & $\begin{array}{l}\text { Medicinal } \\
\text { herb }\end{array}$ & Target viral species & Mechanism \\
\hline (1) Gingerols & $\begin{array}{l}\text { Zingiber } \\
\text { officinale }\end{array}$ & HRS virus & $\mathrm{N} / \mathrm{I}$ \\
\hline (2) Taepeenin $\mathbf{j}$ & $\begin{array}{l}\text { Caesalpinia } \\
\text { bonducella }\end{array}$ & SARS-COV-19 virus & $\begin{array}{c}\text { Mitigate cytokine storms by } \\
\text { preventing the receptor binding } \\
\text { process }\end{array}$ \\
\hline (3) Allicin & $\begin{array}{l}\text { Allium } \\
\text { sativum }\end{array}$ & $\begin{array}{c}\text { Herpes simplex virus-1 } \\
\text { Herpes simplex virus-2 } \\
\text { Parainfluenza virus-3 } \\
\text { Vaccinia virus } \\
\text { Vesicular stomatitis virus }\end{array}$ & $\begin{array}{c}\text { Disruption of viral envelop and cell } \\
\text { membrane }\end{array}$ \\
\hline (4) Alliin and diallyl sulfide & $\begin{array}{l}\text { Allium } \\
\text { sativum }\end{array}$ & Dengue virus & Reduction of oxidative stress \\
\hline (5) Ajoene & $\begin{array}{l}\text { Allium } \\
\text { sativum }\end{array}$ & Human immunodeficiency virus-1 & $\begin{array}{l}\text { Inhibition of viral reverse } \\
\text { transcriptase and cell attachment }\end{array}$ \\
\hline (6) Allyl methyl thiosulfinate & $\begin{array}{l}\text { Allium } \\
\text { sativum }\end{array}$ & $\begin{array}{c}\text { Herpes simplex virus-1 } \\
\text { Herpes simplex virus-2 } \\
\text { Parainfluenza virus-3 } \\
\text { Vaccinia virus } \\
\text { Vesicular stomatitis virus } \\
\text { Human rhinovirus type } 2\end{array}$ & $\begin{array}{l}\text { Disruption of viral envelop and cell } \\
\text { membrane }\end{array}$ \\
\hline (7) Diallyl trisulfide & $\begin{array}{l}\text { Allium } \\
\text { sativum }\end{array}$ & Human cytomegalovirus; IAV-H1N1 & Inhibit viral DNA synthesis \\
\hline (8) Glycyrrhizin & $\begin{array}{l}\text { Glycyrrhiza } \\
\text { glabra }\end{array}$ & $\begin{array}{l}\text { Herpes simplex virus (HSV-1 and HSV-2) } \\
\text { and severe acute respiratory syndrome } \\
\text { (SARS) coronavirus }\end{array}$ & $\begin{array}{l}\text { Inhibit the plaque formation of } \\
\text { herpes simplex virus (HSV-1 and } \\
\text { HSV-2) } \\
\text { Prevent the replication of the severe } \\
\text { acute respiratory syndrome (SARS) } \\
\text { coronavirus }\end{array}$ \\
\hline $\begin{array}{l}\text { (9) Microlobidene, Farnesiferol C, } \\
\text { Farnesiferol B, Kellerin }\end{array}$ & $\begin{array}{c}\text { Ferula } \\
\text { assafoetida }\end{array}$ & Rhinovirus (HRV-2) & $\begin{array}{l}\text { Prevention of rhinovirus adsorption } \\
\text { (HRV-2) }\end{array}$ \\
\hline $\begin{array}{l}\text { (10) } 8^{\prime} \text {-acetoxy- } 5^{\prime} S- \\
\text { hydroxyumbelliprenin, methyl } \\
\text { galbanate, galbanic acid, conferol }\end{array}$ & $\begin{array}{c}\text { Ferula } \\
\text { assafoetida }\end{array}$ & Influenza A H1N1 virus & $\mathrm{N} / \mathrm{I}$ \\
\hline (11) Gossypol & $\begin{array}{l}\text { Gossypium } \\
\text { herbaceum }\end{array}$ & (HIV-l) human immunodeficiency & Prevented the replication \\
\hline (12) Repandusinic acid & $\begin{array}{l}\text { Phyllanthus } \\
\text { niruri }\end{array}$ & (HIV-l) human immunodeficiency & $\begin{array}{l}\text { Inhibitory effect on HIV-1 reverse } \\
\text { transcriptase }\end{array}$ \\
\hline (13) Withaferin A & $\begin{array}{l}\text { Withania } \\
\text { somnifera }\end{array}$ & Herpes simplex virus & $\begin{array}{l}\text { Inhibits herpes simplex virus's DNA } \\
\text { polymerases }\end{array}$ \\
\hline (14) Curcumin & $\begin{array}{l}\text { Curcuma } \\
\text { longa }\end{array}$ & Influenza viruses $\mathrm{PR} 8, \mathrm{H} 1 \mathrm{~N} 1$, and $\mathrm{H} 6 \mathrm{~N} 1$ & $\mathrm{~N} / \mathrm{I}$ \\
\hline $\begin{array}{l}\text { (15) } 1,2,4,6 \text {-Tetra-O-galloyl- } \beta \text {-D- } \\
\text { glucose }\end{array}$ & $\begin{array}{l}\text { Phyllanthus } \\
\text { emblica }\end{array}$ & $\begin{array}{l}\text { Herpes simplex virus } \\
\text { HSV-1 }\end{array}$ & $\begin{array}{l}\text { Blocking viral attachment and } \\
\text { penetration }\end{array}$ \\
\hline (16) Casuarinin & $\begin{array}{l}\text { Terminalia } \\
\text { arjuna }\end{array}$ & Herpes simplex type 2 viruses (HSV-2) & Inhibition of viral penetration \\
\hline
\end{tabular}

N/I: not identified.

arjuna to investigate its antigen inhibitory capability (Infectious Bursal Disease, IBD) of specific T cell populations evaluating the lymphocyte proliferation and CD14- monocyte surface markers in PBMCs (human peripheral blood mononuclear cells). The findings have exhibited that the aqueous leaf extract of T. arjuna showed a significant drop down in CD14 and IBD monocyte surface markers in PBMCs at higher doses [121].
3.19. Azadirachta indica. Azadirachta indica (neem) is a tree belonging to the Meliaceae family. It has been originated in southern and southeastern Asia. A. indica widespread in tropical and subtropical areas of Asia, Africa, America, and Australia. It is an evergreen, deciduous, fast-growing plant which can reach a height of 25 meters [122].

Neem has been extensively used in indigenous medicinal systems such as Ayurveda by Indians for over 2000 years. It 
is traditionally used for the healing of various diseases [123]. Traditional use of A.indica as an antiviral efficacy to recommend for the treatment of bovine and avian poxvirus infected animals by applying leaf paste directly to infected animal skin [124]. Azadirachtin (Figure 14) contains the seed of the Azadirachta indica which recognize as a major constituent.

Badam et al. et al. reported that the methanolic extract of $A$. indica leaves inhibited the plaque formation of many serotypes of coxsackievirus B. In addition to flavonoids, triterpenoids, and their glycosides, the presence of a battery of compounds in the extract has antiviral activity against the coxsackie $B$ virus community in vitro [125]. Neem oil demonstrated strong antiviral activity by preventing the replication of poliovirus [126]. In vitro, the antiviral activity of the aqueous neem leaf extract evaluated clone cells of larvae of Aedes albopictus using virus inhibition assay showed dose-dependent inhibition of dengue 2 viruses [127]. Mahmood et al. stated that the neem bark extract showed significant inhibition for Newcastle disease virus (NDV) [128]. An in silico docking study conducted by Ashfaq et al. revealed that phytochemicals present in $A$. indica leave having antiviral activity against $\mathrm{HCV}$ NS3 protease where 3-deacetyl-3-cinnamoyl-azadirachtin possesses appropriate binding properties with hepatitis $\mathrm{C}$ virus NS3/4A protease and it can be concluded that deacetyl-3-cinnamoyl-azadirachtin serves as a potential inhibitor against the studied protease [129].

3.20. Ficus religiosa. Ficus religiosa is a member of the family Moraceae [130]. It is considered the most sacred tree of South Asia, and different parts of the plant have been extensively used in traditional medicinal systems such as Ayurveda and Unani for various disorders [131]. F. religiosa is known by more than 150 names, and it is native to the sub-Himalayan tract, central India, and Bengal. It has been extensively distributed across the world through cultivation $[132,133]$. Phytochemical studies carried out on F.religiosa revealed phytosterols, furanocoumarins, amino acids, phenolic components, aliphatic alcohols, hydrocarbons, volatile components, and some other classes of secondary metabolites isolated from the different parts of the plant. Phenolic components (flavonoids and tannins) and amino acids are found in almost all parts of the plant $[132,134]$.

F. religiosa extracts have been used in indigenous medicine to treat sexually transmitted diseases (STDs) such as gonorrhea and genital ulcers. Water and chloroform extracts of F. religiosa bark have been showing efficacy against herpes simplex virus type 2 (HSV-2) and, most notably, have demonstrated antiviral activity against acyclovir-resistant strain HSV-2. In addition, the water extract of $F$. religiosa bark has the ability to direct inactivating virus activity. Overall, the extract of chloroform interferes with viral attachment and viral entry as well as restricts the generation of viral progeny [131]. Cagno et al. reported that F. religiosa methanolic bark extract yielded good antiviral action against human rhinovirus whereas this extract inhibited the late steps of the viral replicative cycle. The aqueous bark extract was the most effective as an antirespiratory syncytial virus.
Both partial viral inactivation and virus attachment interference were found to be responsible for the anti-RSV activity. The replication of both tested viruses was inhibited [130].

Table 2 summarized the importance of secondary metabolites extracted from the selected medicinal herbs and antiviral mechanisms revealed by the different research studies. Those studies would be the initial steps for discovering of effective drugs against viral diseases.

\section{Conclusions}

Most significant medicinal plants which are frequently used as antiviral treatments in Ayurveda medicine have been subjected to recent research studies, and specifically, bioactive compounds have been isolated and identified as antiviral phytocompounds against different human infected viral species. Gingerols extracted from Zingiber officinale as the major phytocompound would be the most significant phytocompound inhibiting HRSV activities, computational investigation has discovered that Taepeenin J can be obtained from Caesalpinia bonducella as a promising candidate for receptor inhibition process to mitigate cytokine storms due to the infection of the SARS-CoV-19 virus, ajoene and allicin extracted from the Allium sativum have exhibited for significant anti-HIV and antiherpes simplex virus capabilities, respectively, glycyrrhizin from the Glycyrrhiza glabra is more effective in the regulation of viral replication and can be used as a prophylactic measure, and it was also used to prevent the replication of the severe acute respiratory syndrome (SARS) coronavirus. The key pigment of cotton seed was gossypol, a phenolic compound that has antiviral properties against enveloped viruses, including HIV-1, HSV-2, influenza, and parainfluenza. A polyphenol compound isolated from Phyllanthus emblica, named 1,2,4,6-tetra-O-galloyl- $\beta$-D-glucose, has been documented in vitro for antiviral activity against herpes simplex virus, casuarinin, a hydrolyzable tannin isolated from the Terminalia arjuna bark, has antiviral activity on herpes simplex type 2 viruses (HSV-2), and sesquiterpene cumarines isolated from the oligo-gum resin of Ferula assafoetida showed antiviral properties against rhinovirus (HSV) and influenza A H1N1 virus. Additionally, water and other solvent extracts of the selected herbs have exhibited critical antiviral activities against different disease-forming viral species. Hence, more studies need to be focused on the bioactive constitutes of the medicinal herbs for developing as antiviral drugs.

\section{Conflicts of Interest}

The authors declare no conflict of interest.

\section{Acknowledgments}

The authors would like to acknowledge Mrs. Sachini Rathanaskera, Amila T. Kannangara, and S. Hemal for providing data sources and proofreading the article. 


\section{References}

[1] Y. Tsuchiya, M. Shimizu, Y. Hiyama et al., "Antiviral activity of natural occurring flavonoids in vitro," Chemical and Pharmaceutical Bulletin, vol. 33, no. 9, pp. 3881-3886, 1985.

[2] C. R. Andrighetti-Fröhner, T. C. Sincero, A. C. da Silva et al., "Antiviral evaluation of plants from Brazilian Atlantic Tropical Forest," Fitoterapia, vol. 76, no. 3-4, pp. 374-378, 2005.

[3] P. Pietta, C. Gardana, and A. Pietta, Flavonoids in Health and Disease, C. Rice-Evans and L. Packer, Eds., Marcel Dekker Inc, New York/Basel, 2003.

[4] T. Watkins, W. Resch, D. Irlbeck, and R. Swanstrom, "Selection of High-Level Resistance to Human Immunodeficiency Virus Type 1 Protease Inhibitors," Antimicrobial Agents and Chemotherapy, vol. 47, no. 2, pp. 759-769, 2003.

[5] I. Ahmad, F. Aqil, and M. Owais, Modern Phytomedicine: Turning Medicinal Plants into Drugs, John Wiley \& Sons, 1st edition, 2006.

[6] Y. L. Siow, Y. Gong, K. K. Au-Yeung, C. W. Woo, P. C. Choy, and O. Karmin, "Emerging issues in traditional Chinese medicine," Canadian Journal of Physiology and Pharmacology, vol. 83, no. 4, pp. 321-334, 2005.

[7] D. Webster, P. Taschereau, T. D. Lee, and T. Jurgens, "Immunostimulant properties of Heracleum maximum Bartr.," Journal of Ethnopharmacology, vol. 106, no. 3, pp. 360-363, 2006.

[8] K. G. C. Dissanayake, W. P. R. T. Perera, and N. Premasinghe, "Immunomodulatory efficiency of Tinospora cordifolia against viral infections," World Journal of Pharmaceutical and Medical Research, vol. 6, no. 5, pp. 2228, 2020.

[9] M. J. Abad, J. A. Guerra, P. Bermejo, A. Irurzun, and L. Carrasco, "Search for antiviral activity in higher plant extracts," Phytotherapy Research, vol. 14, no. 8, pp. 604$607,2000$.

[10] K. W. Martin and E. Ernst, "Antiviral agents from plants and herbs: a systematic review," Antiviral Therapy, vol. 8, p. 77, 2003.

[11] B. Havsteen, "Flavonoids, a class of natural products of high pharmacological potency," Biochemical Pharmacology, vol. 32, no. 7, pp. 1141-1148, 1983.

[12] K. G. C. Dissanayake, B. T. Perera, and W. P. R. T. Perera, "Potential of the pathogenic microorganisms' mitigation using rhizome extract of Acorus calamus as a medicinal herb," World Journal of Pharmacy and Pharmaceutical Sciences, vol. 9, 2020.

[13] K. C. G. Dissanayake, W. S. K. Fernando, and W. P. R. T. Perera, "Investigation of the phytochemistry of Coriandrum sativum to combat against viral infections," International Journal of Innovative Pharmaceutical Sciences and Research, vol. 8, no. 6, pp. 1-10, 2020.

[14] H. Kuper, H.-O. Adami, and D. J. Trichopoulos, "Infections as a major preventable cause of human cancer," Journal of Internal Medicine, vol. 248, no. 3, pp. 171-183, 2000.

[15] F. M. Tolo, G. M. Rukunga, F. W. Muli et al., "Anti-viral activity of the extracts of a Kenyan medicinal plant Carissa edulis against herpes simplex virus," Journal of Ethnopharmacology, vol. 104, no. 1-2, pp. 92-99, 2006.

[16] T. Merry and S. Astrautsova, "Alternative approaches to antiviral treatments: focusing on glycosylation as a target for antiviral therapy," Biotechnology and Applied Biochemistry, vol. 56, no. 3, pp. 103-109, 2010.
[17] S. H. Nile and S. W. Park, "Chromatographic analysis, antioxidant, anti-inflammatory, and xanthine oxidase inhibitory activities of ginger extracts and its reference compounds," Industrial Crops and Products, vol. 70, pp. 238-244, 2015.

[18] Y. A. Han, C. W. Song, W. S. Koh et al., “Anti-inflammatory effects of the Zingiber officinale roscoe constituent 12dehydrogingerdione in lipopolysaccharide-stimulated raw 264.7 cells," Phytotherapy Research, vol. 27, no. 8, pp. 1200$1205,2013$.

[19] J. S. Chang, K. C. Wang, C. F. Yeh, D. E. Shieh, and L. C. Chiang, "Fresh ginger (Zingiber officinale) has anti-viral activity against human respiratory syncytial virus in human respiratory tract cell lines," Journal of Ethnopharmacology, vol. 145, no. 1, pp. 146-151, 2013.

[20] S. D. Jolad, R. C. Lantz, A. M. Solyom, G. J. Chen, R. B. Bates, and B. N. Timmermann, "Fresh organically grown ginger (Zingiber officinale): composition and effects on LPSinduced $\mathrm{PGE}_{2}$ production," Phytochemistry, vol. 65 , no. 13, pp. 1937-1954, 2004.

[21] S. D. Jolad, R. C. Lantz, G. J. Chen, R. B. Bates, and B. N. Timmermann, "Commercially processed dry ginger (Zingiber officinale): Composition and effects on LPS-stimulated $\mathrm{PGE}_{2}$ production," Phytochemistry, vol. 66, no. 13, pp. 1614-1635, 2005.

[22] R. Dolin, "Common viral respiratory infections," in Harrison's Principles of Internal Medicine, D. L. Longo, A. S. Fauci, A. S. Fauci, D. L. Kasper, S. L. Hauser, J. L. Jameson, and J. Loscalzo, Eds., pp. 1485-1492, McGraw-Hill, New York, 2012.

[23] V. Subbiah, P. Nagaraja, P. Narayan, and H. G. Nagendra, "Evaluation of pharmacological properties of Caesalpinia bonducella seed and shell extract," The Pharmacogenomics Journal, vol. 11, no. 1, pp. 150-154, 2019.

[24] C. P. Khare, Indian Medicinal Plants: An Illustrated Dictionary, Springer, New York, 2007.

[25] M. L. Dhar, M. M. Dhar, B. N. Dhawan, and B. N. Mehrotra, "Ray C screening of Indian plants for biological activity. Part I," Indian Journal of Experimental Biology, vol. 6, pp. 232247, 1968.

[26] R. M. H. Rajapaksa, B. T. Perera, M. J. Nisansala, W. P. R. T. Perera, and K. G. C. Dissanayake, "Potential of inhibiting the receptor binding mechanism of SARS-COV-2 using phytochemical extracts of medicinal herb; molecular docking study," Global Journal of Engineering Science and Research Management, vol. 7, no. 4, 2020.

[27] P. Mehrbod, E. Amini, and M. Tavassoti-Kheiri, "Antiviral activity of garlic extract on influenza virus," Iranian Journal of Virology, vol. 3, no. 1, pp. 19-23, 2009.

[28] J. C. Harris, S. L. Cottrell, S. Plummer, and D. Lloyd, "Antimicrobial properties of Allium sativum (garlic)," Applied Microbiology and Biotechnology, vol. 57, no. 3, pp. 282-286, 2001.

[29] F. Fraschini, G. Demartini, and D. Esposti, "Pharmacology of silymarin," Clinical Drug Investigation, vol. 22, no. 1, pp. 5165, 2002.

[30] T. M. Shojai, A. G. Langeroudi, V. Karimi, A. Barin, and N. Sadri, "The effect of Allium sativum (garlic) extract on infectious bronchitis virus in specific pathogen free embryonic egg," Avicenna journal of phytomedicine, vol. 6, no. 4, p. $458,2016$.

[31] M. A. Meléndez-Villanueva, K. Morán-Santibañez, J. J. Martínez-Sanmiguel et al., "Virucidal activity of gold 
nanoparticles synthesized by green chemistry using garlic extract," Viruses, vol. 11, no. 12, 2019.

[32] N. D. Weber, D. O. Andersen, J. A. North, B. K. Murray, L. D. Lawson, and B. G. Hughes, "In VitroVirucidal effects of Allium sativum (Garlic) extract and compounds," Planta Medica, vol. 58, no. 5, pp. 417-423, 1992.

[33] N. L. Guo, D. P. Lu, G. L. Woods et al., "Demonstration of the anti-viral activity of garlic extract against human cytomegalovirus in-vitro," Chinese Medical Journal, vol. 106, no. 2, pp. 93-96, 1993.

[34] K. A. Szychowski, K. Rybczyńska-Tkaczyk, K. Gaweł-Bęben et al., "Characterization of active compounds of different garlic (Allium sativum L.) cultivars," Polish Journal of Food and Nutrition Sciences, vol. 68, no. 1, pp. 73-81, 2018.

[35] S. Kun, S. Seetaha, P. Pongsanarakul, S. Hannongbua, and K. Choowongkomon, "Anti-HIV-1 reverse transcriptase activities of hexane extracts from some Asian medicinal plants," Journal of Medicinal Plants Research, vol. 5, no. 19, pp. 4899-4960, 2011.

[36] A. Hall, A. Troupin, B. Londono-Renteria, and T. M. Colpitts, "Garlic organosulfur compounds reduce inflammation and oxidative stress during dengue virus infection," Viruses, vol. 9, no. 7, p. 159, 2017.

[37] A. V. Tatarintsev, P. V. Vrzhets, D. E. Ershov et al., "The ajoene blockade of integrindependent processes in an HIVinfected cell system," Vestnik Rossliskol Akademii Meditsinskikh Nauk, vol. 11-12, pp. 6-9, 1992.

[38] T. Kaul, E. Middleton, and P. Ogra, "Antiviral effect of flavonoids on human viruses," Journal of Medical Virology, vol. 15, no. 1, pp. 71-79, 1985.

[39] F. Feng, L. Hong, C. Wen, and D. Yongsui, “Treatment of hepatitis caused by cytomegalovirus with allitridin injection-an experimental study," Journal of Tongji Medical University, vol. 19, no. 4, pp. 271-274, 1999.

[40] D. M. Biondi, C. Rocco, and G. Ruberto, "New Dihydrostilbene derivatives from the leaves ofGlycyrrhizaglabraand evaluation of their antioxidant activity," Journal of Natural Products, vol. 66, no. 4, pp. 477-480, 2003.

[41] G. V. Obolentseva, V. I. Litvinenko, A. S. Ammosov, T. P. Popova, and A. M. Sampiev, "Pharmacological and therapeutic properties of licorice preparations (a review)," Pharmaceutical Chemistry Journal, vol. 33, no. 8, pp. 427-434, 1999.

[42] L. Badam, "In vitro antiviral activity of indigenous glycyrrhizin, licorice and glycyrrhizic acid (Sigma) on Japanese encephalitis virus," The Journal of Communicable Diseases, vol. 29, pp. 91-99, 1997.

[43] V. Sharma, R. C. Agrawal, and S. Pandey, "Phytochemical screening and determination of antibacterial and antioxidant potential of Glycyrrhiza glabra root extracts," Journal of Environmental Research and Development, vol. 7, no. 4A, pp. 1552-1558, 2013.

[44] L. Badam, "In vitro studies on the effect of glycyrrhizin from Glycyrrhiza glabra on some RNA and DNA viruses," Indian Journal of Pharmacology, vol. 26, pp. 194-199, 1994.

[45] J. Asghari, V. Atabaki, E. Baher, and M. Mazaheritehrani, "Identification of sesquiterpene coumarins of oleo-gum resin of Ferula assa-foetida L. from the Yasuj Region," Natural product research, vol. 30, no. 3, pp. 350-353, 2016.

[46] K. G. C. Dissanayake and W. P. R. T. Perera, "Medicinal importance of Ferula asafetida oligo-gum resins against infective diseases," Journal of Medicinal Plants Studies, vol. 8, no. 2, pp. 135-139, 2020.

[47] J. M. Rollinger, T. M. Steindl, D. Schuster et al., "Structurebased virtual screening for the discovery of natural inhibitors for human rhinovirus coat protein," Journal of Medicinal Chemistry, vol. 51, no. 4, pp. 842-851, 2008.

[48] Y. Ninomiya, M. Aoyama, I. Umeda, Y. Suhara, and H. Ishitsuka, "Comparative studies on the modes of action of the antirhinovirus agents Ro 09-0410, Ro 09-0179, RMI15,731, 4', 6-dichloroflavan, and enviroxime.," Antimicrobial agents and chemotherapy, vol. 27, no. 4, pp. 595-599, 1985.

[49] C. Lee, L. Chiang, L. Cheng et al., "Influenza A (H1N1) antiviral and cytotoxic agents fromFerula assa-foetida," Journal of natural products, vol. 72, no. 9, pp. 1568-1572, 2009.

[50] P. Kanetkar, R. Singhal, and M. Kamat, "Gymnema sylvestre: a memoir," Journal of Clinical Biochemistry and Nutrition, vol. 41, no. 2, pp. 77-81, 2007.

[51] G. P. Dateo and L. Long, "Gymnemic acid, the antisaccharine principle of Gymnema sylvestre. isolation and heterogeneity of gymnemic acid A1," Journal of Agricultural and Food Chemistry, vol. 21, no. 5, pp. 899-903, 1973.

[52] M. S. Subashini and P. Rajendran, "Original research article in vitro screening of anti HBV and anti HIV properties of Gymnema sylvestre R. Br leaves from Kolli Hills, Tamilnadu, India," International Journal of Current Microbiology and Applied Sciences, vol. 4, no. 3, pp. 542-547, 2015.

[53] S. Rupanar and S. Pingale, "Review: phytochemical and pharmacological profile of," International Journal Of Engineering Technology Science and Research, vol. 5, no. 3, pp. 756-764, 2018.

[54] G. Subba Rao, J. Sinsheimer, and K. Cochran, "Antiviral activity of triterpenoid saponins containing acylated $\beta$ amyrin aglycones," Journal of Pharmaceutical Sciences, vol. 63, no. 3, pp. 471-473, 1974.

[55] J. Sinsheimer, G. Subba Rao, H. M. McIlhenny, R. V. Smith, H. F. Maassab, and K. W. Cochran, "Isolation and antiviral activity of the gymnemic acids," Experientia, vol. 24, no. 3, pp. 302-303, 1968.

[56] K. Raheman and A. Sultana, "Gossypium herbaceum Linn: an ethnopharmacological review," Journal of Pharmaceutical and Scientific Innovation (JPSI), vol. 1, 2012.

[57] A. E. Al-snafi, "Chemical constituents and pharmacological activities of Gossypium herbaceum and Gossypium hirsutum - a review Prof," IOSR Journal of Pharmacy, vol. 8, no. 5, pp. 64-80, 2018.

[58] B. Polsky, S. J. Segal, P. A. Baron, J. W. Gold, H. Ueno, and D. Armstrong, "Inactivation of human immunodeficiency virus in vitro by gossypol," Contraception, vol. 39, no. 6, pp. 579-587, 1989.

[59] L. Tai-Shun, R. F. Schinazi, J. Zhu et al., "Anti-HIV-1 activity and cellular pharmacology of various analogs of gossypol," Biochemical pharmacology, vol. 46, no. 2, pp. 251-255, 1993.

[60] A. E. Al-snafi, "Iraqi medicinal plants with antiviral effect-a review Iraqi medicinal plants with antiviral effect- a review," IOSR Journal of Pharmacy, vol. 9, no. 8, pp. 22-103, 2019.

[61] N. Y. S. Lee, W. K. S. Khoo, M. Akmal, and T. Prasat, "The pharmacological potential of Phyllanthus niruri," Journal of Pharmacy and Pharmacology, vol. 68, pp. 953-969, 2016.

[62] S. F. Yeh, C. Y. Hong, Y. L. Huang, T. Y. Liu, K. B. Choo, and C. K. Chou, "Effect of an extract from Phyllanthus amarus on hepatitis B surface antigen gene expression in human 
hepatoma cells," Antiviral Research, vol. 20, no. 3, pp. 185192, 1993.

[63] P. S. Venkateswaran, I. Millman, and B. S. Blumberg, "Effects of an extract from Phyllanthus niruri on hepatitis B and woodchuck hepatitis viruses: in vitro and in vivo studies," Proceedings of the National Academy of Sciences of the United States of America, vol. 84, no. 1, pp. 274-278, 1987.

[64] T. Ogata, H. Higuchi, S. Mochida et al., "HIV-1 reverse transcriptase inhibitor fromPhyllanthus niruri," AIDS Research and Human Retroviruses, vol. 8, no. 11, pp. 1937-1944, 1992.

[65] W. C. Tan, I. B. Jaganath, R. Manikam, and S. D. Sekaran, "Evaluation of antiviral activities of four local Malaysian phyllanthus species against herpes simplex viruses and possible antiviral target," International Journal of Medical Sciences, vol. 10, no. 13, pp. 1817-1829, 2013.

[66] M. R. Moein, K. Zomorodian, K. Pakshir, F. Yavari, M. Motamedi, and M. M. Zarshenas, "Trachyspermum ammi(L.) Sprague," Journal of evidence-based complementary \& alternative medicine, vol. 20, no. 1, pp. 50-56, 2015.

[67] S. Roy, P. Chaurvedi, and A. Chowdhary, "Evaluation of antiviral activity of essential oil of Trachyspermum ammi against Japanese encephalitis virus," Pharmacognosy research, vol. 7, no. 3, pp. 263-267, 2015.

[68] V. K. Bharti, J. K. Malik, and R. C. Gupta, "Ashwagandha: multiple health benefits," in In Nutraceuticals: Efficacy, Safety and Toxicity, pp. 717-733, Elsevier, 2016.

[69] S. K. Kulkarni, A. Sharma, A. Verma, and M. K. Ticku, "GABA receptor mediated anticonvulsant action of Withania somnifera root extract," Indian Drugs, vol. 30, 1993.

[70] A. Grandhi, A. M. Mujumdar, and B. Patwardhan, "A comparative pharmacological investigation of ashwagandha and ginseng," Journal of Ethnopharmacology, vol. 44, no. 3, pp. 131-135, 1994.

[71] T. Ambwani and V. Umapathi, "Antiviral activity of ashwagandha extract on infectious bursal disease virus replication," Indian Journal of Science and Technology, vol. 5, 2015.

[72] S. N. Arseculeratne, A. A. L. Gunatilaka, R. G. Panabokke, and R. G. Panabokke, "Studies on medicinal plants of Sri Lanka. Part 14: toxicity of some traditional medicinal herbs," Journal of Ethnopharmacology, vol. 13, no. 3, pp. 323-335, 1985.

[73] A. Grover, V. Agrawal, A. Shandilya, V. S. Bisaria, and D. Sundar, "Non-nucleosidic inhibition of herpes simplex virus DNA polymerase: mechanistic insights into the antiherpetic mode of action of herbal drug withaferin A," BMC Bioinformatics, vol. 12, Supplement 13, 2011.

[74] P. R. Usha, M. U. Naidu, and Y. S. Raju, "Evaluation of the antiretroviral activity of a new polyherbal drug (Immu-25) in patients with HIV infection," Drugs in $R$ \& $D$, vol. 4, no. 2, pp. 103-109, 2003.

[75] W. W. Chao and B. F. Lin, "Isolation and identification of bioactive compounds in Andrographis paniculata (Chuanxinlian)," Chinese medicine, vol. 5, no. 1, pp. 17-17, 2010.

[76] C. Wiart, K. Kumar, M. Y. Yusof, H. Hamimah, Z. M. Fauzi, and M. Sulaiman, "Antiviral properties of ent-labdene diterpenes of Andrographis paniculata Nees, inhibitors of herpes simplex virus type 1," Phytotherapy Research, vol. 19, no. 12, pp. 1069-1070, 2005.

[77] C. Calabrese, S. H. Berman, J. G. Babish et al., "A phase I trial of andrographolide in HIV positive patients and normal volunteers," Phytotheraphy Research, vol. 14, no. 5, pp. 333-338, 2000 .
[78] L. L. P. King Spalding, "Andrographolide derivatives to treat viral infections,” US Patent 20060333785, 2006.

[79] T. P. Lin, S. Y. Chen, P. D. Duh, L. K. Chang, and Y. N. Liu, "Inhibition of the Epstein-Barr virus lytic cycle by andrographolide," Biological \& Pharmaceutical Bulletin, vol. 31, no. 11, pp. 2018-2023, 2008.

[80] L. I. C. Tang, A. P. K. Ling, R. Y. Koh, S. M. Chye, and K. G. L. Voon, "Screening of anti-dengue activity in methanolic extracts of medicinal plants," BMC Complementary and Alternative Medicine., vol. 12, no. 1, pp. 1-10, 2012.

[81] R. N. Chopra, S. L. Nayar, and I. C. Chopra, Glossary of Indian medicinal plants (including the supplement), Council of Scientific and Industrial Research, New Delhi, 1986.

[82] B. Singh and R. P. Rastogi, "A reinvestigation of the triterpenes of Centella asiatica," Phytochemistry, vol. 8, no. 5, pp. 917-921, 1969.

[83] R. Srivastava, Y. N. Shukla, and S. Kumar, "Chemistry and pharmacology of Centella asiatica: a review," Journal of Medicinal and Aromatic Plant Sciences, vol. 19, pp. 10491056, 1997.

[84] E. Williamson, "Centella asiatica (L.) Urb," in Major Herbs of Ayurveda, E. Williamson, Ed., pp. 102-110, Elsevier Science, London, UK, 2002.

[85] C. Yoosook, N. Bunyapraphatsara, Y. Boonyakiat, and C. Kantasuk, "Anti-herpes simplex virus activities of crude water extracts of Thai medicinal plants," Phytomedicine, vol. 6, no. 6, pp. 411-419, 2000.

[86] H. Hanisa, M. L. Mohdazmi, M. Suhaila, and M. N. Hakim, "Effects of Centella asiatica L., Curcuma longa L., and Strobilanthescrispus L. extracts on 3 kidney cell lines: in vitro cytotoxicity analysis," International Journal of Pharmacy and Pharmaceutical Sciences, vol. 6, pp. 388-392, 2014.

[87] R. K. Singh, D. Rai, D. Yadav, A. Bhargava, J. Balzarini, and E. De Clercq, "Synthesis, antibacterial and antiviral properties of curcumin bioconjugates bearing dipeptide, fatty acids and folic acid," European Journal of Medicinal Chemistry, vol. 45, no. 3, pp. 1078-1086, 2010.

[88] D.-Y. Chen, J.-H. Shien, L. Tiley et al., "Curcumin inhibits influenza virus infection and haemagglutination activity," Food Chemistry, vol. 119, no. 4, pp. 1346-1351, 2010.

[89] K. Zandi, E. Ramedani, K. Mohammadi et al., "Evaluation of antiviral activities of curcumin derivatives against HSV-1 in Vero cell line," Natural Product Communications, vol. 5, no. $12,2010$.

[90] C. S. Divya and M. R. Pillai, "Antitumor action of curcumin in human papillomavirus associated cells involves downregulation of viral oncogenes, prevention of $\mathrm{NFkB}$ and AP-1 translocation, and modulation of apoptosis," Molecular Carcinogenesis, vol. 45, no. 5, pp. 320-332, 2006.

[91] K. Dutta, D. Ghosh, and A. Basu, "Curcumin protects neuronal cells from Japanese encephalitis virus-mediated cell death and also inhibits infective viral particle formation by dysregulation of ubiquitin-proteasome system," Journal of Neuroimmune Pharmacology, vol. 4, no. 3, pp. 328337, 2009.

[92] K. Basu, "Indian Medicinal Plants," in Lalith Mohan Basu, pp. 1074-1076, Jayyd Press, Allahabad, India, 2nd edition edition, 1992.

[93] A. Ghani, Medicinal Plants of Bangladesh with Chemical Constituents and Uses, Asiatic Society of Bangladesh, Dhaka, Bangladesh, 2003. 
[94] S. Chanda, Y. Baravalia, and M. Kaneria, "Protective effect of Polyalthia longifolia var. pendula leaves on ethanol and ethanol/HCl induced ulcer in rats and its antimicrobial potency," Asian Pacific Journal of Tropical Medicine, vol. 4, no. 9, pp. 673-679, 2011.

[95] A. S. Shah and A. R. Juvekar, "In vitroandin vivoimmunostimulatory activity of Woodfordia fruticosa flowers on non-specific immunity," Pharmaceutical Biology, vol. 48, no. 9, pp. 1066-1072, 2010.

[96] D. Brinda and R. Geetha, "Evaluation of the protective efficacy of Woodfordia fruticosa on phenytoin induced liver damage in rats," Journal of cell and tissue research, vol. 9, no. 3, pp. 1981-1984, 2009.

[97] T. Yoshida, T. Chou, A. Nitta et al., "A macro-ring hydrolyzable tannin dimer with antitumor activity, and accompanying dimers from Woodfordia fruticosa flowers," Chemical and Pharmaceutical Bulletin, vol. 38, no. 5, pp. 1211-1217, 1990.

[98] N. Verma, G. Amresh, P. K. Sahu, N. Mishra, C. V. Rao, and A. P. Singh, "Wound healing potential of flowers extract of Woodfordia fruiticosa Kurz," Indian Journal of Biochemistry \& Biophysics, vol. 50, pp. 296-304, 2013.

[99] P. Palese and M. L. Shaw, "Orthomyxoviridae: the viruses and their replication," in Fields Virology, D. M. Knipe and P. M. Howley, Eds., pp. 1648-1689, Lippincott Williams \& Wilkins, Philadelphia, 2006.

[100] J. M. Kratz, C. R. Andrighetti-Fröhner, D. J. Kolling et al., "Anti-HSV-1 and anti-HIV-1 activity of gallic acid and pentyl gallate," Memórias do Instituto Oswaldo Cruz, vol. 103, no. 5, pp. 437-442, 2008.

[101] D. W. Unander, G. L. Webster, and B. S. Blumberg, "Usage and bioassays in Phyllanthus (Euphorbiaceae). IV. Clustering of antiviral uses and other effects," Journal of Ethnopharmacology, vol. 45, no. 1, pp. 1-18, 1995.

[102] Habib-ur-Rehman, K. A. Yasin, M. A. Choudhary et al., "Studies on the chemical constituents ofPhyllanthus emblica," Natural Product Research, vol. 21, no. 9, pp. 775781, 2007.

[103] Y. Xiang, Y. Pei, C. Qu et al., "In vitroAnti-Herpes simplex virus activity of 1,2,4,6-Tetra-O-galloyl- $\beta$-d-glucose from Phyllanthus emblica L. (Euphorbiaceae)," Phytotherapy Research, vol. 25, no. 7, pp. 975-982, 2011.

[104] Q. Liu, Y.-F. Wang, R.-J. Chen et al., "Anti-coxsackie virus B3 norsesquiterpenoids from the roots ofPhyllanthus emblica," Journal of Natural Products, vol. 72, no. 5, pp. 969-972, 2009.

[105] J.-J. Lv, S. Yu, Y. Xin et al., "Anti-viral and cytotoxic norbisabolane sesquiterpenoid glycosides from Phyllanthus emblica and their absolute configurations," Phytochemistry, vol. 117, pp. 123-134, 2015.

[106] R. Rathinamoorthy and G. Thilagavathi, "Terminalia chebula - review on pharmacological and biochemical studies," International Journal of PharmTech Research, vol. 6, no. 1, pp. 97116, 2014.

[107] C. P. Khare, Indian Medicinal Plants - An Illustrated Dictionary, 1st Indian Reprint, New Delhi, 2007.

[108] V. Badmaev and M. Nowakowski, "Protection of epithelial cells against influenza A virus by a plant derived biological response modifier Ledretan-96," Phytotherapy Research, vol. 14, no. 4, pp. 245-249, 2000.

[109] M. Kurokawa, K. Nagasaka, T. Hirabayashi et al., "Efficacy of traditional herbal medicines in combination with acyclovir against herpes simplex virus type 1 infection in vitro and in vivo," Antiviral Research, vol. 27, no. 1-2, pp. 19-37, 1995.

[110] S. E. Mekkawy, M. R. Meselhy, I. T. Kusumoto, S. Kadota, M. Hattori, and T. Namba, "Inhibitory effects of Egyptian folk medicines on human immunodeficiency virus (HIV) reverse transcriptase," Chemical and pharmaceutical bulletin, vol. 43, no. 4, pp. 641-648, 1995.

[111] I. Ahmad, Z. Mehmood, and F. Mohammad, "Screening of some Indian medicinal plants for their antimicrobial properties," Journal of Ethnopharmacology, vol. 62, no. 2, pp. 183193, 1998.

[112] H. Ma, Y. D. Zhao, K. Li, and T. Kang, "A new alternative to treat swine influenza A virus infection: extracts from Terminalia chebula Retz," African Journal of Microbiology Research, vol. 4, no. 6, pp. 497-499, 2010.

[113] O. S. Ajala, A. Jukov, and C. M. Ma, "Hepatitis C virus inhibitory hydrolysable tannins from the fruits of Terminalia chebula," Fitoterapia, vol. 99, pp. 117-123, 2014.

[114] C. S. Kumar and S. Bhattacharya, "Tamarind seed: properties, processing and utilization," Critical Reviews in Food Science and Nutrition, vol. 48, no. 1, pp. 1-20, 2008.

[115] E. De Caluw, K. Halamov, and P. Van Damme, “Tamarindus indica L. a review of traditional uses, phytochemistry and pharmacology," Afrika Focus, vol. 23, no. 1, pp. 53-83, 2010.

[116] P. Kuru, "Tamarindus indica and its health related effects," Asian Pacific Journal of Tropical Biomedicine, vol. 4, no. 9, pp. 676-681, 2014.

[117] O. O. Okoh, G. E. Obiiyeke, U. U. Nwodo, and A. I. Okoh, "Ethanol extract and chromatographic fractions of Tamarindus indica stem bark inhibits Newcastle disease virus replication," Pharmaceutical Biology, vol. 55, no. 1, pp. 1806-1808, 2017.

[118] S. Dwivedi, “Terminalia arjuna Wight \& Arn.-A useful drug for cardiovascular disorders," Journal of Ethnopharmacology, vol. 114, no. 2, pp. 114-129, 2007.

[119] F. E. King, T. J. King, and J. M. Ross, "Terminalia arjuna and its chemical constituents," Journal of the Chemical Society, vol. 85, p. 399, 1954.

[120] H. Y. Cheng, C. C. Lin, and T. C. Lin, "Antiherpes simplex virus type 2 activity of casuarinin from the bark of Terminalia arjuna Linn.," Antiviral Research, vol. 55, no. 3, pp. 447-455, 2002.

[121] S. A. Rasmussen, D. J. Jamieson, M. A. Honein, and L. R. Petersen, "Zika virus and birth defects-reviewing the evidence for causality," The New England Journal of Medicine, vol. 374, no. 20, pp. 1981-1987, 2016.

[122] H. Schmutterer, "Properties and potential of natural pesticides from the neem Tree, Azadirachta Indica," Annual review of entomology, vol. 35, no. 1, pp. 271-297, 1990.

[123] L. C. Faccin-Galhardi, K. Aimi Yamamoto, S. Ray, B. Ray, R. E. Carvalho Linhares, and C. Nozawa, "The in vitro antiviral property of Azadirachta indica polysaccharides for poliovirus," Journal of Ethnopharmacology, vol. 142, no. 1, pp. 8690, 2012.

[124] K. Biswas, I. Chattopadhyay, R. K. Banerjee, and U. Bandyopadhyay, "Biological activities and medicinal properties of neem (Azadirachta indica)," Current science, vol. 82, no. 11, pp. 1336-1345, 2002.

[125] L. Badam, S. P. Joshi, and S. S. Bedekar, "'In vitro'antiviral activity of neem (Azadirachta indica. A. Juss) leaf extract 
against group B coxsackieviruses," The Journal of Communicable Diseases, vol. 31, no. 2, pp. 79-90, 1999.

[126] M. SaiRam, G. Ilavazhagan, S. K. Sharma et al., "Anti-microbial activity of a new vaginal contraceptive NIM-76 from neem oil (Azadirachta indica)," Journal of Ethnopharmacology, vol. 71, no. 3, pp. 377-382, 2000.

[127] M. M. Parida, C. Upadhyay, G. Pandya, and A. M. Jana, "Inhibitory potential of neem (Azadirachta indica Juss) leaves on Dengue virus type-2 replication," Journal of Ethnopharmacology, vol. 79, no. 2, pp. 273-278, 2002.

[128] M. S. Mahmood, H. W. Amir, R. Z. Abbas, A. Rafique, and B. Aslam, "Evaluation of antiviral activity of Azadirachta indica (Neem) bark extract against Newcastle disease virus," Pakistan Veterinary Journal, vol. 38, no. 1, pp. 25-28, 2018.

[129] U. A. Ashfaq, A. Jalil, and M. T. ul Qamar, "Antiviral phytochemicals identification fromAzadirachta indicaleaves against HCV NS3 protease: an in silico approach," Natural Product Research, vol. 30, no. 16, pp. 1866-1869, 2016.

[130] V. Cagno, A. Civra, R. Kumar et al., "Ficus religiosa L. bark extracts inhibit human rhinovirus and respiratory syncytial virus infection in vitro," Journal of Ethnopharmacology, vol. 176, pp. 252-257, 2015.

[131] M. Ghosh, A. Civra, M. Rittà et al., "Ficus religiosa L. bark extracts inhibit infection by herpes simplex virus type 2 in vitro," Archives of Virology, vol. 161, no. 12, pp. 3509$3514,2016$.

[132] D. Singh, B. Singh, and R. K. Goel, "Traditional uses, phytochemistry and pharmacology of Ficus religiosa : A review," Journal of Ethnopharmacology, vol. 134, no. 3, pp. 565-583, 2011.

[133] A. E. Al-Snafi, "Pharmacology of Ficus religiosa-a review," IOSR Journal of Pharmacy, vol. 7, no. 3, pp. 49-60, 2017.

[134] M. S. Manorenjitha, A. K. Norita, S. Norhisham, and M. Z. Asmawi, "GC-MS analysis of bioactive components of Ficus religiosa (Linn.) stem," International Journal of Pharma and Bio Sciences, vol. 4, no. 2, pp. 99-103, 2013. 